\title{
17. PRELIMINARY ORGANIC ANALYSES OF DSDP CORES, LEG 14, ATLANTIC OCEAN ${ }^{1}$
}

\author{
Bernd R. Simoneit, E. Sloan Scott, and A. L. Burlingame, Space Sciences Laboratory, University of California, Berkeley
}

\begin{abstract}
Organic carbon-rich samples from Sites 138 and 144 of DSDP Leg 14 were analyzed. A sample of Oligocene age yielded mainly alkanes, $\mathrm{C}_{n} \mathrm{H}_{2 n+2}$ for $n=19$ to 36 with an odd over even predominance; carboxylic acid methyl esters (formed by clay catalysis with solvent methanol), $\mathrm{C}_{n} \mathrm{H}_{2 n} \mathrm{O}_{2}$ for $n=14$ to 25 with an even over odd predominance; and steranes (e.g. cholestane, ergostane, and stigmastane), sterones, and triterpanes. The other samples, all of Cretaceous age, yielded mainly alkanes, $\mathrm{C}_{n} \mathrm{H}_{2 n+2}$ for $n=19$ to $30^{+}$with no significant predominance; carboxylic acid methyl esters, $\mathrm{C}_{n} \mathrm{H}_{2 n} \mathrm{O}_{2}$ for $n=14$ to 24 with no predominance; and sterones and steranes probably of marine origin. These Cretaceous sediments contain large amounts of kerogen and the extractable petroliferous material appears to have gone through maturation processes.
\end{abstract}

\section{INTRODUCTION}

Organic carbon-rich samples from two drill sites of Leg 14 were analyzed. Site $138\left(25^{\circ} 55.4^{\prime} \mathrm{N}, 25^{\circ} 33.8^{\prime} \mathrm{W}\right)$ was cored in the abyssal hills (water depth $5288 \mathrm{~m}$ ) at the foot of the continental rise, about $870 \mathrm{~km}$ west of Cap Blanc, West Africa (Hayes et al., 1971). The upper sample is of Oligocene age (approximately 35 m.y.) and consists of dark olive gray clay. The lower sample is of close to middle Cretaceous age (approximately 90-100 m.y.) and consists of a mixture of clay, dolomite, silt, and carbonaceous black clayey mud, all occurring just above an altered aphanitic basalt layer (Pimm, personal communication). Site 144 $\left(9^{\circ} 27.2^{\prime} \mathrm{N}, 54^{\circ} 20.5^{\prime} \mathrm{W}\right)$ was cored on the northern flank of the Demerara Rise (water depth $2957 \mathrm{~m}$ ) approximately $400 \mathrm{~km}$ north of Surinam (Hayes et al., 1971). Four organic carbon-rich samples, all of upper Cretaceous age (range approximately $80-93$ m.y.), were analyzed from this core. The samples from 181.0 and 190.1 meters below the seabed consist of black zeolitic, calcareous clays and fine laminated black shale. Large quantities of hydrogen sulfide were encountered at this level and the sequence was interbedded with marly limestone (Pimm, personal communication). The samples from 214.7 and 216.1 meters below the seabed consist of laminated dark olive gray calcareous clay with significant amounts of organic particulate matter and fossil foraminifera and nannoplankton. Again large quantities of hydrogen sulfide were encountered at this level. Similar organic-rich laminated sediments from the Black Sea and the Mediterranean Sea have been analyzed (Simoneit, in press; Simoneit et al., in press), and Site 105 in the western Atlantic Ocean also yielded some organic-rich clay sediments (Simoneit et al., 1972).

\footnotetext{
${ }^{1}$ Manuscript received too late to be included in Volume 14.
}

\section{EXPERIMENTAL PROCEDURES}

High resolution mass spectrometric analyses of the benzene/methanol- or tolune/methanol-soluble extracts were carried out on a GEC-AEI MS-902 mass spectrometer on-line to an XDS Sigma 7 computer (described by Burlingame, 1968 and 1970, and Burlingame et al., 1970). The samples were introduced via a ceramic direct inlet probe into the ion source, operated at the following conditions: resolution 10,000 ; ionizing current $500 \mu \mathrm{A}$; ionizing voltage $50 \mathrm{eV}$; and temperature 200 to $220^{\circ} \mathrm{C}$. The scan rate was $16 \mathrm{sec}$ per decade with a clock rate of $24 \mathrm{kHz}$. Multiple scans were taken during each analysis and then sum averaged together during data reduction. Selected high resolution mass spectral data are presented as heteroatomic plots (Burlingame and Smith, 1968) in various figures in the text.

Analyses using gas chromatography-mass spectrometry were carried out on a modified Varian MAT Model 311 GC/MS linked on-line to an XDS Sigma 2 computer (Smith et al., 1971). The GC conditions used in the GC/MS analyses are the same as cited in the respective GC conditions used in the GC/MS analyses are the same as cited in the respective GC figure legends, and the mass spectrometric and computer operating parameters are as reported (Smith et al., 1971). Certain mass spectra from the various GC/MS analyses were identified by use of a compound classifier (Smith, 1972; Chang et al., in preparation).

Gas chromatographic analyses were carried out using a Perkin-Elmer Model 900 gas chromatograph fitted with a flame ionization detector and operating under the conditions stated in the respective figure legends.

All solvents used, e.g., toluene, benzene, methanol, and $n$-heptane were Mallinckrodt Nanograde quality. The toluene, benzene, and methanol were redistilled in an all glass apparatus prior to use. 
All the samples were dried under vacuum $\left(60^{\circ} \mathrm{C}\right.$ and $25 \mathrm{~cm} \mathrm{Hg}$ pressure) and then powdered using a mortar and pestle. The dry weights averaged $3 \mathrm{~g}$. The powders were then extracted in a small, all glass Soxhlet apparatus for 3 to 5 days. After filtration through a fine glass frit the extracts were concentrated on a rotary evaporator (bath at $30-40^{\circ} \mathrm{C}$ ) and then repartitioned into a heptane-diethyl ether-soluble fraction and a tolune/methanol- or benzene/ methanol-soluble fraction. These fractions were not separated further and were subjected directly to GC and mass spectrometric analyses.

\section{RESULTS}

The solvent extract yields from the core samples are listed in Table 1 and the elemental analyses of these samples are found in Table 2.

\section{Site 138}

The two Site 138 samples were subjected to GC, HRMS, and GC/MS analyses. The GC traces for the 117.6 meters sample (14-138-2-6) are shown in Figure 1 and the high resolution mass spectrometric data for the toluene/ methanol-soluble fraction is shown in Figure 2. ${ }^{2}$ The major constituents are hydrocarbons of the series $\mathrm{C}_{n} \mathrm{H}_{2 n+2}$ to $\mathrm{C}_{n} \mathrm{H}_{2 n-12}$, ranging from $n=3$ to 20 ; however, not every homolog has been detected. The peaks of compositions $\mathrm{C}_{14} \mathrm{H}_{23}$ at $\mathrm{m} / \mathrm{e} 191$ (Structure I) and $\mathrm{C}_{16} \mathrm{H}_{25}$ at $\mathrm{m} / \mathrm{e} 217$ (Structure II) are significantly above the background. Contaminants from the core tube (dibutyl esters) or phthalate esters are minor. Carboxylic acids or their esters and other oxygenated higher molecular weight compounds have not been detected.<smiles>[CH2+]C1=CC2(C)CCCC(C)(C)C2CC1</smiles>

I

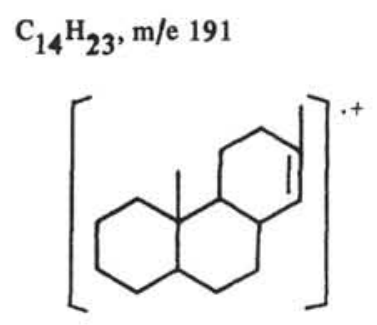

\footnotetext{
${ }^{2}$ In this report, all high resolution mass spectra are presented as heteroatomic plots (Burlingame and Smith, 1968) with the masses plotted in methylene units. On the abscissa, each principal division marker corresponds to the saturated alkyl fragment (even-electron ion), for example, $\mathrm{C}_{n} \mathrm{H}_{2 n+1}$, with the number of carbon and hydrogen atoms given subsequently. Each principal division of the abscissa is further divided into seven units. The number of hydrogen atoms of an unsaturated or cyclic-fragment ion is obtained by subtracting the number of units (two hydrogen atoms) or half-units from the $2 n+1$ hydrogen atoms of the respective saturated principal division, $\mathrm{C}_{n} \mathrm{H}_{2 n+1}$. Fragments with more than seven degrees of unsaturation are plotted with each principal division marker on the
}

The GC/MS data for the heptane/ether-soluble fraction are summarized in Table 3 and the salient features of these data appear in Figure 3. The major constituents are alkanes, $\mathrm{C}_{n} \mathrm{H}_{2 n+2}$, ranging from $n=18$ to 34 with strong odd over even predominance. Methyl esters of carboxylic acids were detected for the series $\mathrm{C}_{n} \mathrm{H}_{2 n} \mathrm{O}_{2}$ ranging from $n=14$ to 25 , with an even over odd predominance. Minor amounts of steranes, sterones, and triterpenes were detected. The major components match well to the standard spectra and consist of cholestane (Structure III), ergostane (Structure IV), and sitostane or stigmastane (Structure V). The sterones belong to the series $\mathrm{C}_{n} \mathrm{H}_{2 n-8} \mathrm{O}$ for $n=27$ to 30 . The mass spectrum (scan 270) in Figure $3 \mathrm{~g}$ fits the fragmentation<smiles>CC(C)CCCC(C)C1CCC2C3CCC4CCCCC4(C)C3CCC12C</smiles>

III $\mathrm{C}_{27} \mathrm{H}_{48}, \mathrm{~m} / \mathrm{e} 371$ IV $\mathrm{C}_{28} \mathrm{H}_{50}, \mathrm{~m} / \mathrm{e} 386$<smiles>CCC(CCC(C)C1CCC2C3CCC4CCCCC4(C)C3CCC12C)C(C)C</smiles>

pattern of cholestanone (Structure VI) as published by Budzikiewicz and Djerassi (1962), exhibiting the molecular ion at $\mathrm{m} / \mathrm{e} 386$ and the base peak at $\mathrm{m} / \mathrm{e} 231$ (Structure VII). The scan 291 spectrum fits the fragmentation pattern

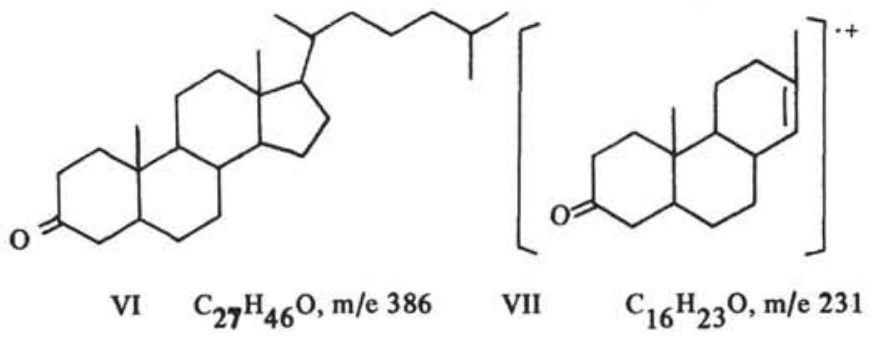

abscissa corresponding to the fragment ion $\mathrm{C}_{n} \mathrm{H}_{2 n-13}$. Each principal division is again further divided into seven units, and the number of hydrogen atoms of a fragment ion is derived as discussed above. The origin of the abscissas is the same $\mathrm{m} / \mathrm{e}$ ratio for each plot, thus the nominal masses, indicated in 50 mass unit intervals below the carbon/hydrogen ratio scale, lie directly above one another from plot to plot. All plots are normalized to a base peak (usually the base peak of the entire spectrum, unless otherwise specified) on the relative intensity scale. In order to make high mass, low intensity features of the spectrum observable, the whole spectrum or any region thereof can be multiplied by a scale factor. This factor is indicated by / $\mathrm{X} 00$ at the point of scale expansion. A composite low resolution mass spectrum for each set of data appears plotted separately at the bottom of the plot series. 
TABLE 1

DSDP Small Core Sample Extracts, Leg 14

\begin{tabular}{lclccc}
\hline Sample & $\begin{array}{c}\text { Depth Below } \\
\text { Seafloor } \\
(\mathrm{m})\end{array}$ & $\begin{array}{c}\text { Approximate } \\
\text { Age }\end{array}$ & $\begin{array}{c}\text { Organic } \\
\text { Carbon } \\
\%^{\mathrm{a}}\end{array}$ & $\begin{array}{c}\text { Heptane/Ether } \\
\text { Extract } \\
\%\end{array}$ & $\begin{array}{c}\text { Benzene/Methanol } \\
\text { Extract } \\
\%\end{array}$ \\
\hline $\begin{array}{l}14-138-2-6 \\
(12-13 \mathrm{~cm})\end{array}$ & 117.6 & Oligocene & 2.3 & 0.15 & 0.42 \\
$\begin{array}{l}14-138-6-3 \\
(49-50 \mathrm{~cm})\end{array}$ & 428.5 & $\begin{array}{l}\text { Middle } \\
\text { Cretaceous }\end{array}$ & 16.8 & 0.44 & 1.22 \\
$\begin{array}{l}14-144 \mathrm{~A}-5-1 \\
(114-116 \mathrm{~cm})\end{array}$ & 181.0 & $\begin{array}{l}\text { Upper } \\
\text { Cretaceous }\end{array}$ & 11.1 & 0.04 & 0.14 \\
$\begin{array}{l}14-144 \mathrm{~A}-6-1 \\
(100-101 \mathrm{~cm})\end{array}$ & 190.1 & $\begin{array}{l}\text { Upper } \\
\text { Cretaceous }\end{array}$ & 10.4 & 0.35 & 0.92 \\
$\begin{array}{l}14-144-4-2 \\
(20-21 \mathrm{~cm})\end{array}$ & 214.7 & $\begin{array}{l}\text { Upper } \\
\text { Cretaceous }\end{array}$ & 10.3 & 0.27 & 0.70 \\
$\begin{array}{l}14-144-4-3 \\
(14-15 \mathrm{~cm})\end{array}$ & 216.1 & $\begin{array}{l}\text { Upper } \\
\text { Cretaceous }\end{array}$ & 6.5 & 0.23 & 1.03 \\
\hline
\end{tabular}

${ }^{\mathrm{a} D a t a}$ supplied by G. Bode, DSDP staff.

TABLE 2

Elemental Analyses of DSDP Core Samples From Leg 14

\begin{tabular}{llrccr}
\hline \multicolumn{1}{c}{ Sample } & & $\begin{array}{c}\text { Total C } \\
(\%)\end{array}$ & $\begin{array}{c}\mathrm{H} \\
(\%)\end{array}$ & $\begin{array}{c}\text { Residue } \\
(\%)\end{array}$ & $\begin{array}{c}\text { Oxygen } \\
(\%)^{\mathrm{a}}\end{array}$ \\
\hline $14-138-2-6$ & dried & 2.59 & 1.56 & 84.9 & 10.9 \\
$(12-13 \mathrm{~cm})$ & extracted & 2.47 & 1.42 & 86.9 & 9.2 \\
$14-138-6-3$ & dried & 11.99 & 1.91 & 76.6 & 9.5 \\
$(49-50 \mathrm{~cm})$ & extracted & 11.21 & 1.79 & 77.9 & 9.1 \\
$14-144 \mathrm{~A}-5-1$ & dried & 11.26 & 0.31 & 62.5 & 25.9 \\
$(114-116 \mathrm{~cm})$ & extracted & 12.72 & 0.34 & 59.4 & 27.5 \\
$14-144 \mathrm{~A}-6-1$ & dried & 16.45 & 1.59 & 62.0 & 20.0 \\
$(100-101 \mathrm{~cm})$ & extracted & 15.54 & 1.50 & 63.3 & 20.7 \\
$14-144-4-2$ & dried & 13.37 & 1.85 & 74.0 & 10.8 \\
$(20-21 \mathrm{~cm})$ & & & & & \\
$14-144-4-3$ & dried & 15.04 & 1.21 & 61.5 & 22.2 \\
$(14-15 \mathrm{~cm})$ & extracted & 13.52 & 1.14 & 62.1 & 23.2 \\
\hline
\end{tabular}

a Determined by difference.

of ergostanone (Structure VIII) and the scan 322 spectrum (cf. Figure $3 \mathrm{~h}$ ) fits for stigmastanone (Structure IX). The triterpanes belong to the series $\mathrm{C}_{n} \mathrm{H}_{2 n-8}$ and $\mathrm{C}_{n} \mathrm{H}_{2 n-10}$ for $n=30$ to 31 . The major peak in these data is due to dibutyl

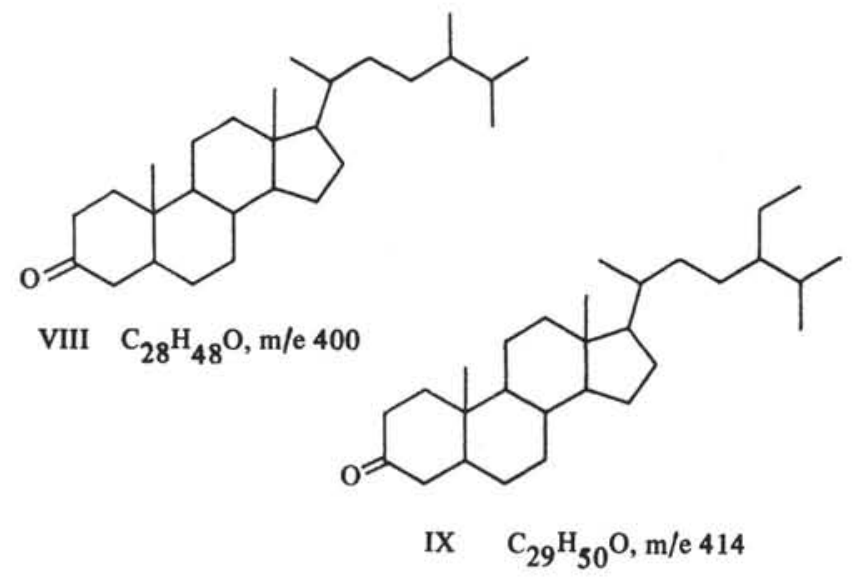

azelate, probably from core tube contamination. Phthalate esters were detected as minor components and probably derive from the sample vial caps.

The scan 191 mass spectrum (cf. Figure $3 \mathrm{f}$ ) occurs at the maximum concentration of an unknown compound of molecular weight 382 , which exhibits a base peak of $\mathrm{m} / \mathrm{e}$ 115 (cf. Figure 3e). The fragmentation pattern appears to fit a diester of glutaric acid, probably octyl (5-cyclopentylpentyl) glutarate, and this compound is a possible contaminant from the core tube material.

The GC traces for the 428.5 meter sample (14-138-6-3) are shown in Figure 4 and the GC/MS data are also summarized in Table 3. The salient features of the GC/MS data are shown in Figure 5. The alkanes, $\mathrm{C}_{n} \mathrm{H}_{2 n+2}$, are again the major constituents of the heltane/ether fraction and range from $n=13$ to 26 with no predominance and maximizing at $n=17$. Significant amounts of carboxylic acid methyl esters are also present; the series $\mathrm{C}_{n} \mathrm{H}_{2 n} \mathrm{O}_{2}$ extends from $n=9$ to 24 with no predominance apparent and maximum at $n=16$. Sterones and minor amounts of steranes and triterpanes were detected. The steranes were in the series $\mathrm{C}_{n} \mathrm{H}_{2 n-6}$ for $n=27$ to 28 ; the sterones, $\mathrm{C}_{n} \mathrm{H}_{2 n-8} \mathrm{O}$, ranged from $n=27$ to 29 (the spectrum of cholestanone and stigmastanone appear in Figure $5 \mathrm{~g}$ and $\mathrm{h}$

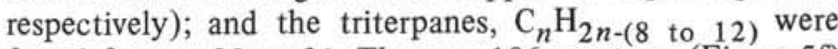
found for $n=30$ to 31 . The scan 106 spectrum (Figure $5 \mathrm{f}$ ) is an unknown compound of molecular weight 250 . Pristane and to a much lesser extent phytane were detected in this sample. Contaminants from the core tube material were also identified, as well as trace amounts of phthalates from the sample vial caps.

\section{Site 144}

The four Site 144 samples were subjected to GC, GC/MS, and HRMS analyses. The GC traces for the 181.0 meter sample (14-144A-5-1) are shown in Figure 6. The GC/MS data of the heptane/ether-soluble fraction are summarized in Table 4 and the salient features are shown in Figure 7. Methyl esters of carboxylic acids are present in 

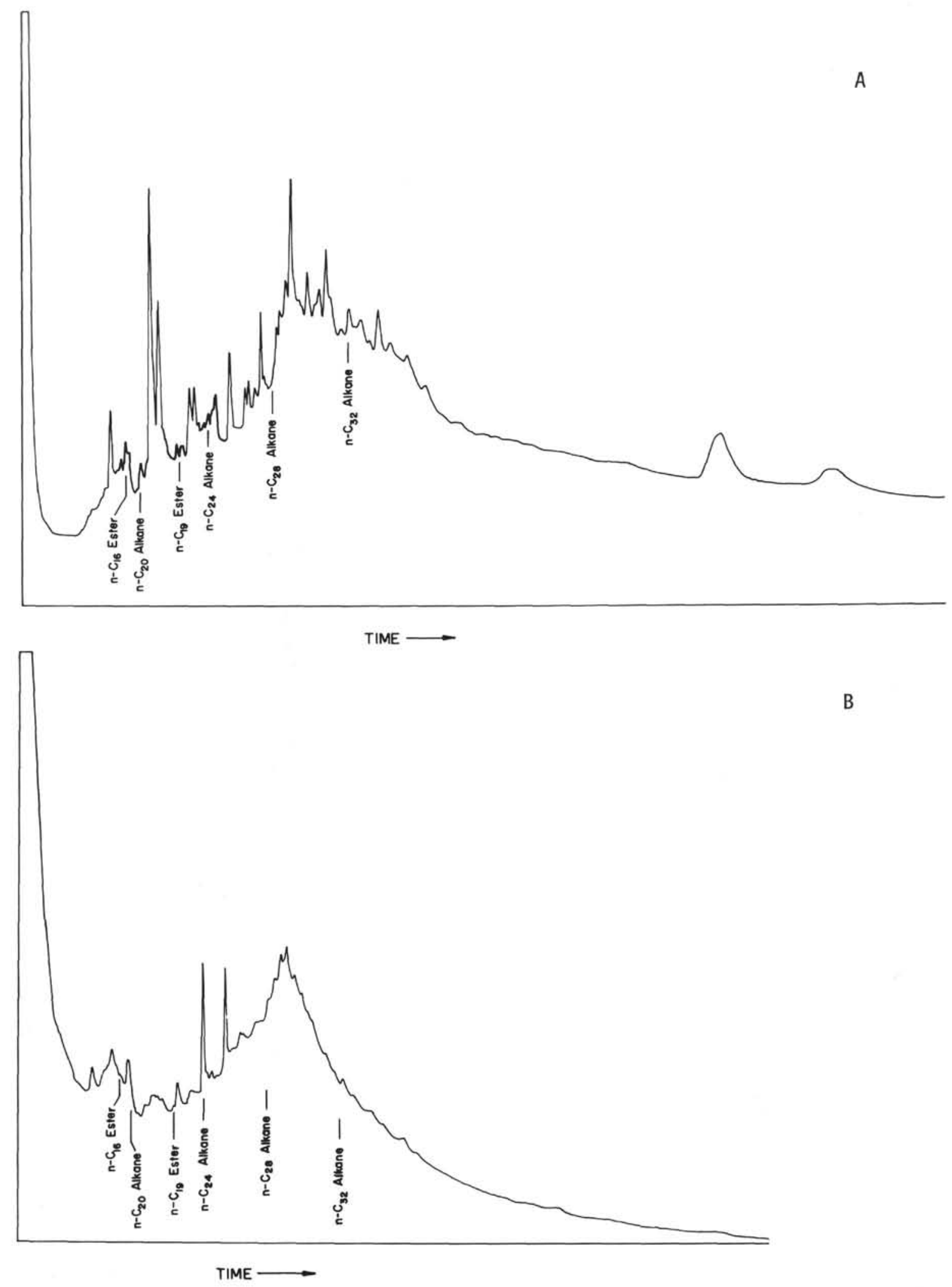

Figure 1a. Gas chromatogram of the heptane/ether-soluble extract fraction from Sample 14-138-2-6 (12-13 cm). /Conditions: $7.5 \mathrm{ft} \times 1 / 8 \mathrm{in}$. stainless steel column packed with 3\% OV-1 on 100-200 mesh gas chrom $Q$, programmed from $100-275^{\circ} \mathrm{C}$ at $8^{\circ} / \mathrm{min}$ and using He carrier gas at $60 \mathrm{ml} / \mathrm{min}$ ). The relative retention times of various normal alkanes and methyl esters of normal carboxylic acids are indicated on the GC traces (determined by coinjection).

Figure 1b. Gas chromatogram of the toluene/methanol-soluble extract fraction from Sample 14-138-2-6 (12-13 cm). (Conditions as cited in Figure 1a). 

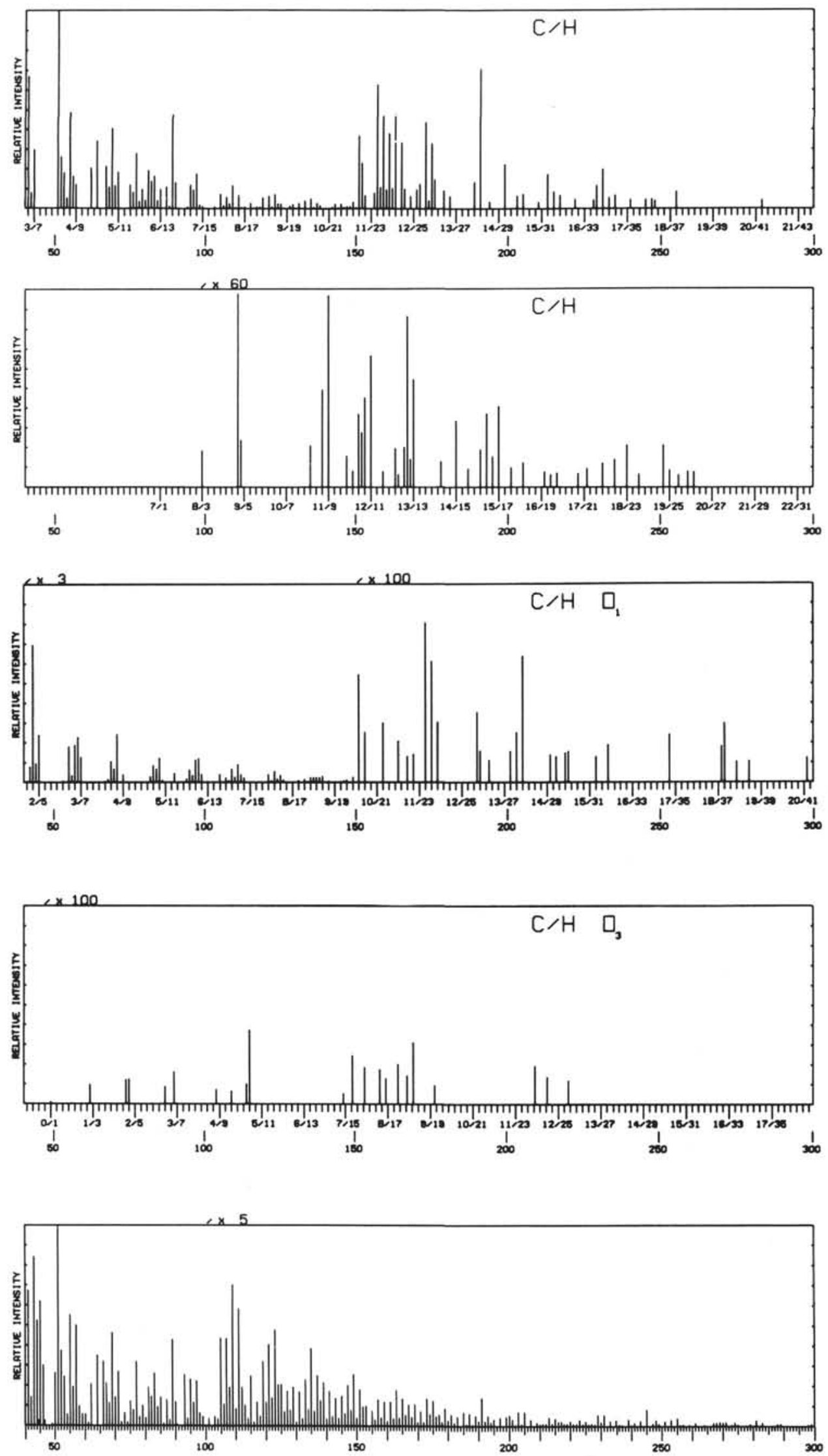

Figure 2. Partial high resolution mass spectrometric data for the toluene- and methanol-soluble fraction from the exhaustive extract of Sample 14-138-2-6 $(12-13 \mathrm{~cm})$. 
B. R. SIMONEIT, E. S. SCOTT, A. L. BURLINGAME

TABLE 3

Major Components of the Heptane/Ether-Soluble Extracts from the Core Samples of DSDP Site 138, Determined by GC/MS

\begin{tabular}{|c|c|c|c|c|}
\hline \multirow[b]{3}{*}{ Compound Name } & & & \multicolumn{2}{|c|}{ Sample } \\
\hline & & & $\begin{array}{l}14-138-2-6 \\
(12-13 \mathrm{~cm})\end{array}$ & $\begin{array}{l}14-138-6-3 \\
(49-50 \mathrm{~cm})\end{array}$ \\
\hline & \multicolumn{2}{|c|}{$\begin{array}{l}\text { Composition and } \\
\text { Molecular Weight }\end{array}$} & $\begin{array}{l}\text { Spectrum Scan No. } \\
\text { (cf. Fig. 3a) }\end{array}$ & $\begin{array}{l}\text { Spectrum Scan No. } \\
\text { (cf. Fig. 5a) }\end{array}$ \\
\hline Methyl $n$-nonanoate & $\mathrm{C}_{10} \mathrm{H}_{20} \mathrm{O}_{2}$ & 172 & n.d. & 5 \\
\hline Methyl caprate & $\mathrm{C}_{11} \mathrm{H}_{22} \mathrm{O}_{2}$ & 186 & n.d. & 17 \\
\hline Acenaphthene & $\mathrm{C}_{12} \mathrm{H}_{10}$ & 154 & n.d. & 27 \\
\hline$n$-Tetradecane & $\mathrm{C}_{14} \mathrm{H}_{30}$ & 198 & n.d. & 30 \\
\hline Methyl $n$-undecanoate & $\mathrm{C}_{12} \mathrm{H}_{24} \mathrm{O}_{2}$ & 200 & n.d. & 33 \\
\hline$n$-Pentadecane & $\mathrm{C}_{15} \mathrm{H}_{32}$ & 212 & n.d. & 48 \\
\hline Methyl laurate & $\mathrm{C}_{13} \mathrm{H}_{26} \mathrm{O}_{2}$ & 214 & n.d. & 52 \\
\hline Diethyl phthalate $^{b}$ & $\mathrm{C}_{12} \mathrm{H}_{14} \mathrm{O}_{4}$ & 222 & n.d. & 65 \\
\hline$n$-Hexadecane & $\mathrm{C}_{16} \mathrm{H}_{34}$ & 226 & n.d. & 71 \\
\hline Methyl $n$-tridecanoate & $\mathrm{C}_{14} \mathrm{H}_{28} \mathrm{O}_{2}$ & 228 & n.d. & 73 \\
\hline$n$-Heptadecane & $\mathrm{C}_{17} \mathrm{H}_{36}$ & 240 & n.d. & 89 \\
\hline Pristane & $\mathrm{C}_{19} \mathrm{H}_{40}$ & 268 & n.d. & 90 \\
\hline Methyl myristate & $\mathrm{C}_{15} \mathrm{H}_{30} \mathrm{O}_{2}$ & 242 & 94 & 91 \\
\hline$n$-Octadecane & $\mathrm{C}_{18} \mathrm{H}_{38}$ & 254 & 114 & 102 \\
\hline Phytane & $\mathrm{C}_{20} \mathrm{H}_{42}$ & 282 & n.d. & 103 \\
\hline Methyl $n$-pentadecanoate & $\mathrm{C}_{16} \mathrm{H}_{32} \mathrm{O}_{2}$ & 256 & 116 & 104 \\
\hline $\begin{array}{l}\text { Unknown } \\
n \text {-Nonadecane }\end{array}$ & $\mathrm{C}_{19} \overline{\mathrm{H}}_{40}$ & $\begin{array}{l}250 \\
268\end{array}$ & $\begin{array}{l}120 \\
137\end{array}$ & $\begin{array}{l}106 \\
113\end{array}$ \\
\hline Methyl palmitate & $\mathrm{C}_{17} \mathrm{H}_{34} \mathrm{O}_{2}$ & 270 & 140 & 115 \\
\hline Dibutyl phthalate ${ }^{b}$ & $\mathrm{C}_{16} \mathrm{H}_{22} \mathrm{O}_{4}$ & 278 & 142 & n.d. \\
\hline$n$-Eicosane & $\mathrm{C}_{20} \mathrm{H}_{42}$ & 282 & 156 & 123 \\
\hline Methyl margarate & $\mathrm{C}_{18} \mathrm{H}_{36} \mathrm{O}_{2}$ & 284 & 158 & 125 \\
\hline Dibutyl azelate & $\mathrm{C}_{17} \mathrm{H}_{32} \mathrm{O}_{4}$ & 300 & 163 & 125 \\
\hline Methyl stearate & $\mathrm{C}_{19} \mathrm{H}_{38} \mathrm{O}_{2}$ & 298 & 170 & 136 \\
\hline$n$-Heneicosane & $\mathrm{C}_{21} \mathrm{H}_{44}$ & 296 & 171 & n.d. \\
\hline Dibutyl sebacate ${ }^{a}$ & $\mathrm{C}_{18} \mathrm{H}_{34} \mathrm{O}_{4}$ & 314 & 173 & 138 \\
\hline$n$-Docosane & $\mathrm{C}_{22} \mathrm{H}_{46}$ & 310 & 178 & n.d. \\
\hline Methyl $n$-nonadecanoate & $\mathrm{C}_{20} \mathrm{H}_{40} \mathrm{O}_{2}$ & 312 & 180 & 146 \\
\hline$n$-Tricosane & $\mathrm{C}_{23} \mathrm{H}_{48}$ & 324 & 186 & n.d. \\
\hline Methyl arachidate & $\mathrm{C}_{21} \mathrm{H}_{42} \mathrm{O}_{2}$ & 326 & 187 & 155 \\
\hline $\begin{array}{l}\text { Unknown } \\
n \text {-Tetracosane }\end{array}$ & $\mathrm{C}_{24} \overline{\mathrm{H}}_{50}$ & $\begin{array}{l}382 \\
338\end{array}$ & $\begin{array}{l}191 \\
195\end{array}$ & $\begin{array}{l}\text { n.d. } \\
\text { n.d. }\end{array}$ \\
\hline Methyl $n$-heneicosanoate & $\mathrm{C}_{22} \mathrm{H}_{44} \mathrm{O}_{2}$ & 340 & 196 & 164 \\
\hline$n$-Pentacosane & $\mathrm{C}_{25} \mathrm{H}_{52}$ & 352 & 204 & n.d. \\
\hline Methyl behenate & $\mathrm{C}_{23} \mathrm{H}_{46} \mathrm{O}_{2}$ & 354 & 205 & 175 \\
\hline Dioctyl phthalate ${ }^{b}$ & $\mathrm{C}_{24} \mathrm{H}_{38} \mathrm{O}_{4}$ & 390 & 206 & n.d. \\
\hline$n$-Hexacosane & $\mathrm{C}_{26} \mathrm{H}_{54}$ & 366 & 215 & n.d. \\
\hline Methyl tricosanoate & $\mathrm{C}_{24} \mathrm{H}_{48} \mathrm{O}_{2}$ & 368 & 217 & 185 \\
\hline$n$-Heptacosane & $\mathrm{C}_{27} \mathrm{H}_{56}$ & 380 & 229 & n.d. \\
\hline Methyl lignocerate & $\mathrm{C}_{25} \mathrm{H}_{50} \mathrm{O}_{2}$ & 382 & 231 & 195 \\
\hline Cholestane & $\mathrm{C}_{27} \mathrm{H}_{48}$ & 372 & 241 & 221 \\
\hline n-Octacosane & $\mathrm{C}_{28} \mathrm{H}_{58}$ & 394 & 244 & n.d. \\
\hline
\end{tabular}




\begin{tabular}{|c|c|c|c|c|}
\hline \multirow{4}{*}{$\frac{\text { Compound Name }}{\text { Methyl pentacosanoate }}$} & & & \multicolumn{2}{|c|}{ Sample } \\
\hline & & & $\begin{array}{l}14-138-2-6 \\
(12-13 \mathrm{~cm})\end{array}$ & $\begin{array}{l}14-138-6-3 \\
(49-50 \mathrm{~cm})\end{array}$ \\
\hline & \multicolumn{2}{|c|}{$\begin{array}{l}\text { Composition and } \\
\text { Molecular Weight }\end{array}$} & $\begin{array}{l}\text { Spectrum Scan No. } \\
\text { (cf. Fig. 3a) }\end{array}$ & $\begin{array}{l}\text { Spectrum Scan No. } \\
\text { (cf. Fig. 5a) }\end{array}$ \\
\hline & $\mathrm{C}_{26} \mathrm{H}_{52} \mathrm{O}_{2}$ & 396 & 248 & n,d. \\
\hline Ergostane & $\mathrm{C}_{28} \mathrm{H}_{50}$ & 386 & 262 & 236 \\
\hline$n$-Nonacosane & $\mathrm{C}_{29} \mathrm{H}_{60}$ & 408 & 263 & n.d. \\
\hline Methyl cerotate & $\mathrm{C}_{27} \mathrm{H}_{54} \mathrm{O}_{2}$ & 410 & 268 & n.d. \\
\hline Triterpane & $\mathrm{C}_{30} \mathrm{H}_{48}$ & 408 & 269 & 284 \\
\hline Cholestanone & $\mathrm{C}_{27} \mathrm{H}_{46} \mathrm{O}$ & 386 & 270 & 291 \\
\hline Sterane & $\mathrm{C}_{29} \mathrm{H}_{50}$ & 398 & 272 & n.d. \\
\hline Stigmastane (sitostane) & $\mathrm{C}_{29} \mathrm{H}_{52}$ & 400 & 272 & 282 \\
\hline$n$-Triacontane & $\mathrm{C}_{30} \mathrm{H}_{62}$ & 422 & 288 & n.d. \\
\hline Sterone & $\mathrm{C}_{28} \mathrm{H}_{48} \mathrm{O}$ & 400 & 291 & 332 \\
\hline Sterane & $\mathrm{C}_{30} \mathrm{H}_{54}$ & 414 & 294 & n.d. \\
\hline$n$-Hentriacontane & $\mathrm{C}_{31} \mathrm{H}_{64}$ & 436 & 315 & n.d. \\
\hline Triterpane & $\mathrm{C}_{30} \mathrm{H}_{50}$ & 410 & 316 & 332 \\
\hline Triterpane & $\mathrm{C}_{30} \mathrm{H}_{52}$ & 412 & 316 & 332 \\
\hline Methyl octacosanoate & $\mathrm{C}_{29} \mathrm{H}_{58} \mathrm{O}_{2}$ & 438 & 321 & n.d. \\
\hline Stigmastanone & $\mathrm{C}_{29} \mathrm{H}_{50} \mathrm{O}$ & 414 & 322 & 364 \\
\hline Dotriacontane & $\mathrm{C}_{32} \mathrm{H}_{66}$ & 450 & 346 & n.d. \\
\hline Sterone & $\mathrm{C}_{30} \mathrm{H}_{52} \mathrm{O}$ & 428 & 352 & n.d. \\
\hline$n$-Tritriacontane & $\mathrm{C}_{33} \mathrm{H}_{68}$ & 464 & 384 & n.d. \\
\hline Triterpane & $\mathrm{C}_{31} \mathrm{H}_{54}$ & 426 & 385 & 386 \\
\hline Tetratriacontane & $\mathrm{C}_{34} \mathrm{H}_{70}$ & 478 & 419 & n.d. \\
\hline
\end{tabular}

almost equal abundance; the series $\mathrm{C}_{n} \mathrm{H}_{2 n} \mathrm{O}_{2}$ ranges from $n=14$ to 22 , also with no specific predominance and a bimodal maximum at $n=16$ and 18 (cf. Figure $7 \mathrm{c}$ ). Small amounts of steranes and triterpanes were detected. The steranes found are in the series $\mathrm{C}_{n} \mathrm{H}_{2 n-6}$ ranging from $n=$ 27 to 29 and two triterpanes, $\mathrm{C}_{30} \mathrm{H}_{48}$ and $\mathrm{C}_{30} \mathrm{H}_{54} \mathrm{O}$, were detected. The major sterane components match the fragmentation patterns of cholestane (Structure III), ergostane (Structure IV), and sitostane (Structure V) respectively. Each of the spectra exhibiting the triterpane compositions (i.e., molecular ions, $\mathrm{M} \cdot \mathrm{CH}_{3}$, and large $\mathrm{m} / \mathrm{e} 191$ peaks) is a mixture of several compounds. Minor amounts of phthalate ester contaminants were detected. An unknown compound of molecular weight 476 , possible composition $\mathrm{C}_{34} \mathrm{H}_{68}$, and the less saturated homolog at $\mathrm{m} / \mathrm{e} 474$, were detected. These compounds have a base peak at $\mathrm{m} / \mathrm{e} 213$ (cf. Figure $7 \mathrm{~d})$.

The GC traces for the 190.1 meter sample (14-144A-6-1) are shown in Figure 8. The GC/MS data of the heptane/ ether-soluble fraction are summarized in Table 4 and the salient features are shown in Figure 9. There were two major component series present in this case. The carboxylic acids (detected as the methyl esters) of the series $\mathrm{C}_{n} \mathrm{H}_{2 n} \mathrm{O}_{2}$ ranged from $n=14$ to 24 , with no predominance and a maximum at $n=16$ (cf. Figure 9c). An unknown group of compounds exhibiting molecular ions at $\mathrm{m} / \mathrm{e} 490,488,476$, $474,460,446$, and 444 were present, with the homolog at $\mathrm{m} / \mathrm{e} 476$ (cf. scan 300 in Figure 9h) being the most abundant. These compounds exhibit a base peak at $\mathrm{m} / \mathrm{e} 213$ (cf. Figure 9d) and were found in minor amounts at the 181.0 meter level of this core. No known chemical structures could at this time be fit to the mass spectrometric fragmentation pattern of these compounds; however, from the ratio of the ${ }^{13} \mathrm{C}$ isotope parent peak to the parent ion, the compositional series $\mathrm{C}_{n} \mathrm{H}_{2 n}$ (for $n=34$ and 35 ) and $\mathrm{C}_{n} \mathrm{H}_{2 n-2}$ (for $n=32$ to 35 ) appear to fit the data best. The compound of mass 476 (cf. Figure $9 \mathrm{~h}$ ) fragments by losing: $\mathrm{CH}_{3}$ to $\mathrm{m} / \mathrm{e} 461, \mathrm{C}_{6} \mathrm{H}_{13}$ to $\mathrm{m} / \mathrm{e} 391$, and $\mathrm{C}_{8} \mathrm{H}_{17}$ to $\mathrm{m} / \mathrm{e} 363$, which indicates an isoprenoidal $\mathrm{C}_{8}$ sidechain.

The alkanes were found in lesser amounts. The series $\mathrm{C}_{n} \mathrm{H}_{2 n+2}$ ranged from $n=16$ to 30 , with a slight odd over even predominance and maximizing at $n=17$. There is also a large amount of iso-tetradecane in this mixture (cf. scan 45 in Figure 9f). The mass spectrum (cf. scan 159 in Figure 


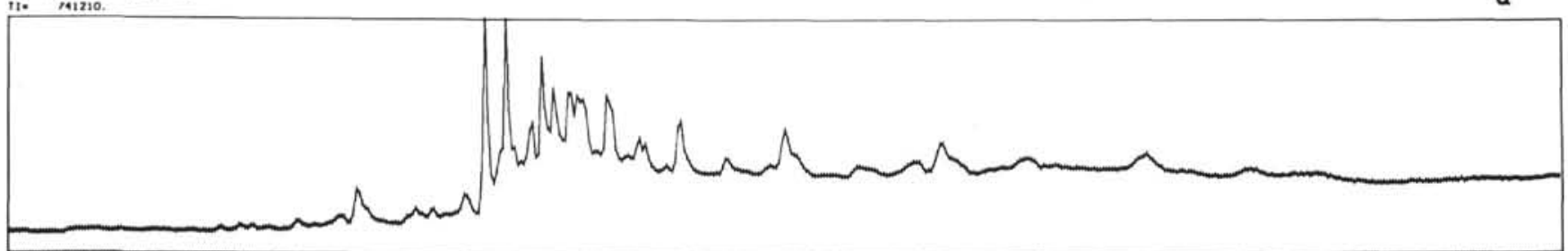

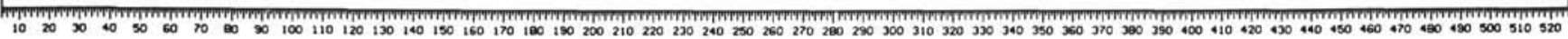

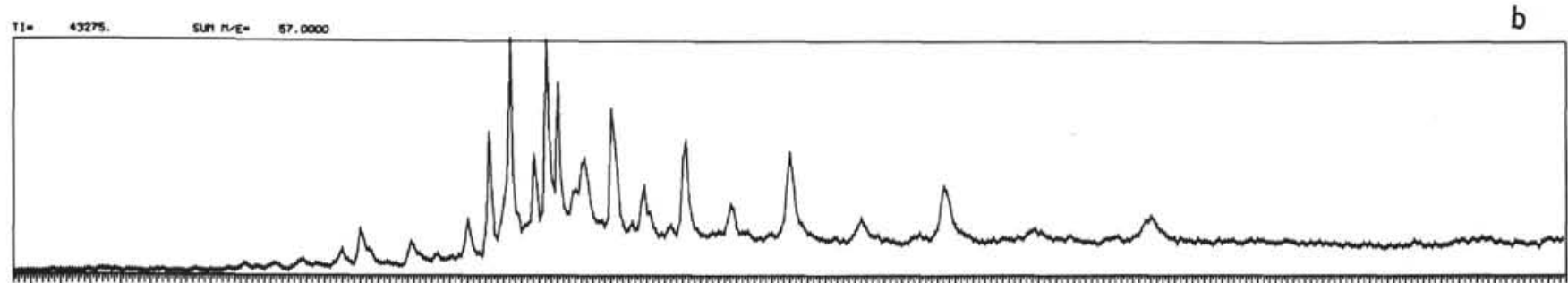

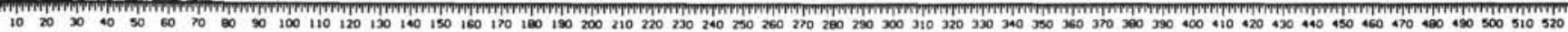
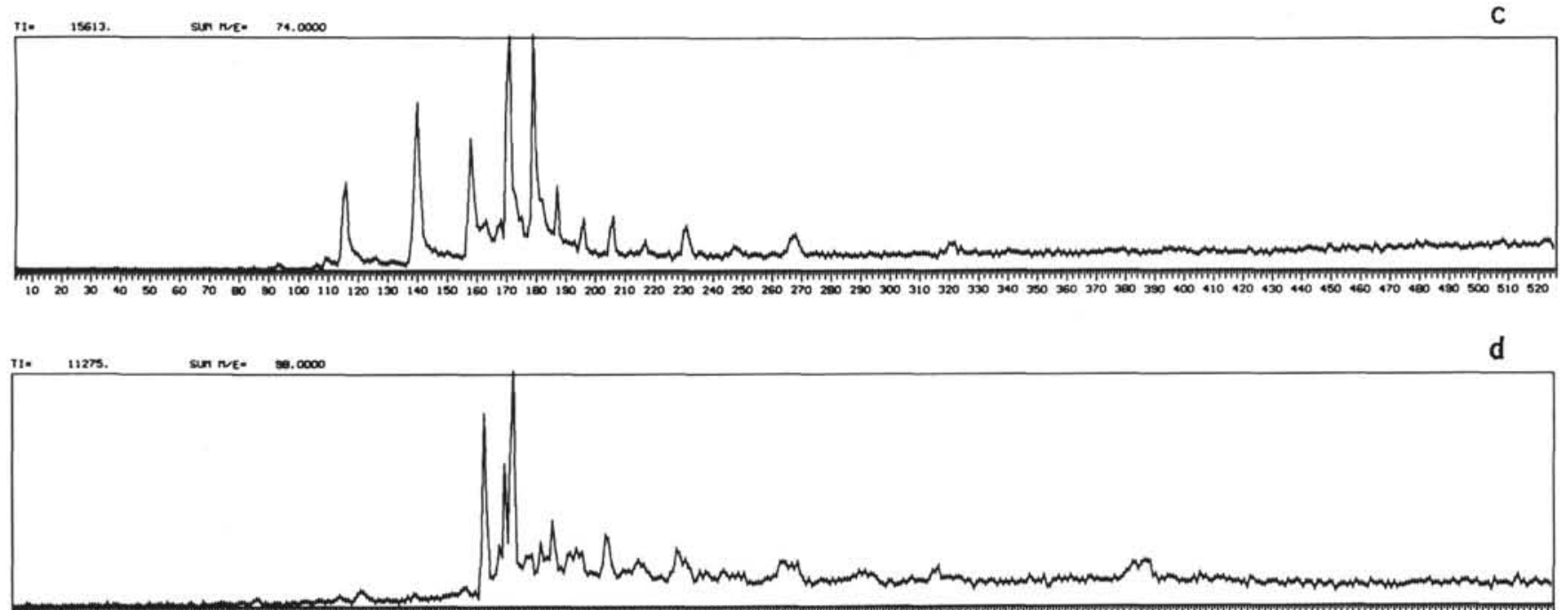

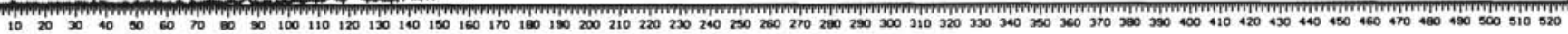

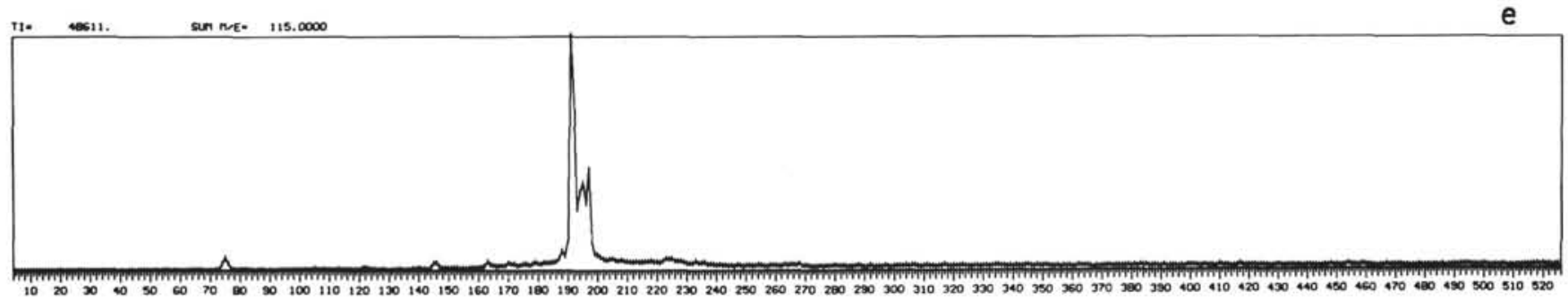

Figure 3. GC/MS data for total heptane-soluble extract from Sample 14-138-2-6 (12-13 cm). (GC conditions as cited in Figure 1a).

a) total ionization sum plot.

b) $\mathrm{m} / \mathrm{e} 57$ sum plot.

c) $m / e 74$ sum plot.

d) $\mathrm{m} / \mathrm{e} 98$ sum plot.

e) $\mathrm{m} / \mathrm{e} 115 \mathrm{sum}$ plot.

f) Mass spectrum scan 191 (unknown, M-382).

g) mass spectrum scan 270 (cholestanone).

h) mass spectrum scan 322 (stigmastanone). 


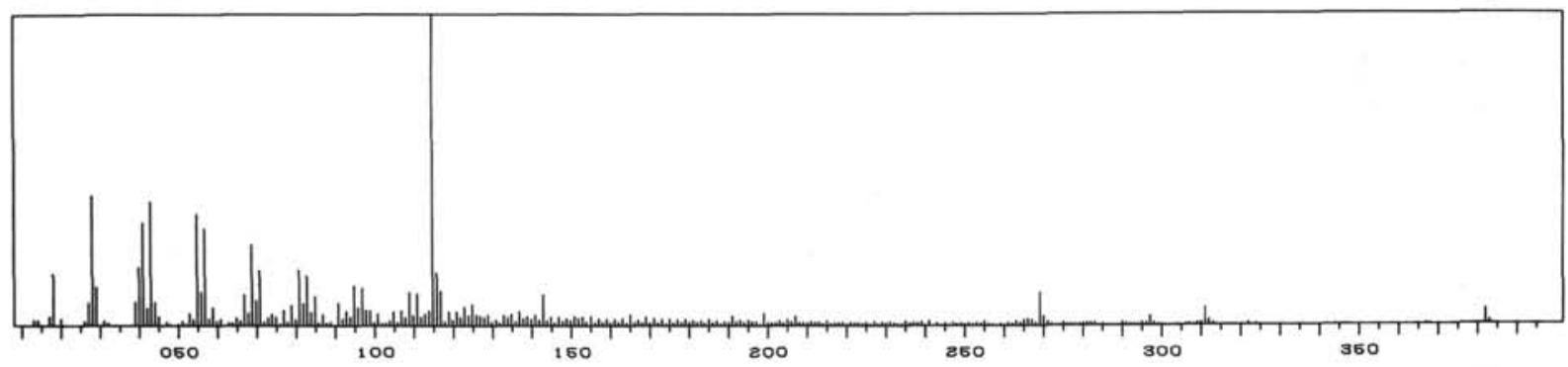

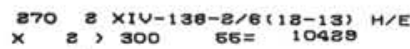

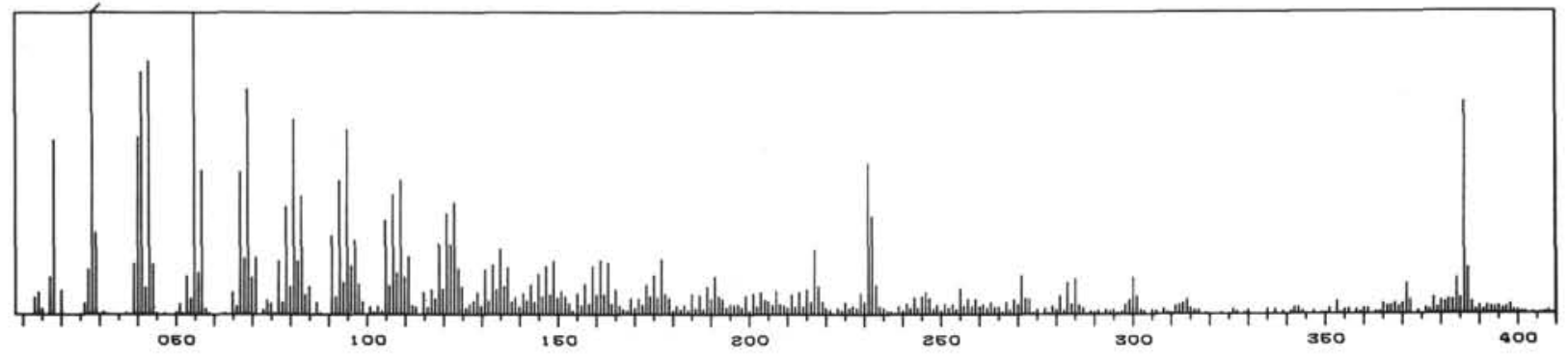

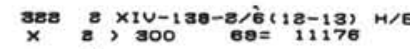

h

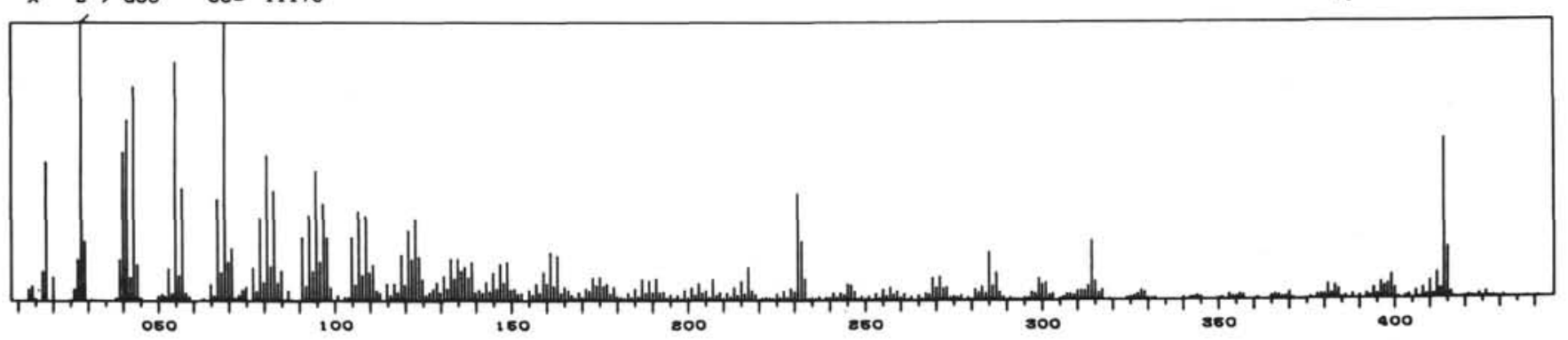

Figure 3. (Continued).

9g) of the largest peak in the GC trace (cf. Figure 8a) fits the fragmentation pattern of dibutyl azelate. The homologs $n=17$ to 19 of this series, $\mathrm{C}_{n} \mathrm{H}_{2 n-2} \mathrm{O}_{4}$ were detected and are probably derived from core tube contamination. Phthalate ester contaminants were not found.

The GC traces for the 214.7 meter sample (14-144-4-2) are shown in Figure 10 and the high resolution mass spectrometric data of the toluene- and methanol-soluble fraction are shown in Figure 11. A low amount of dibutyl phthalate is present, as indicated by the peaks of compositions $\mathrm{C}_{8} \mathrm{H}_{5} \mathrm{O}_{3}, \mathrm{C}_{8} \mathrm{H}_{7} \mathrm{O}_{4}, \mathrm{C}_{12} \mathrm{H}_{15} \mathrm{O}_{4}$, and $\mathrm{C}_{16} \mathrm{H}_{22} \mathrm{O}_{4}$. Significant amounts of hydrocarbons are present for the series $\mathrm{C}_{n} \mathrm{H}_{2 n+2}$ to $\mathrm{C}_{n} \mathrm{H}_{2 n-14}$ for $n=3$ to 30 , however, not every homolog was detected. Minor amounts of sterols or sterones of the series $\mathrm{C}_{n} \mathrm{H}_{2 n-8} \mathrm{O}$ and $\mathrm{C}_{n} \mathrm{H}_{2 n-10} \mathrm{O}$ for $n=27$ to 29 were also found in this sample. The peaks at $\mathrm{m} / \mathrm{e} 217$ of composition $\mathrm{C}_{16} \mathrm{H}_{25}$ (Structure II) and at $\mathrm{m} / \mathrm{e} 215$ of composition $\mathrm{C}_{16} \mathrm{H}_{23}$ (Structure $\mathrm{X}$ ) are significantly above the background, corroborating the presence of steroidal compounds. Carboxylic acids or their esters were not detected in these data.

The GC traces of the 216.1 meter sample (14-144-4-3) are shown in Figure 12. The GC/MS data are summarized in Table 4 and the salient features are shown in Figure 13. The

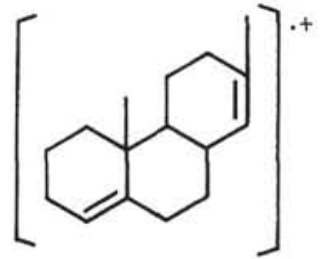

$\mathrm{X} \quad \mathrm{C}_{16} \mathrm{H}_{23}, \mathrm{~m} / \mathrm{e} 215$

GC trace of the heptane/ether-soluble fraction strongly resembles the GC trace of the same fraction of the 214.7 meter sample (14-144 4-2) (cf. Figure 10a). The major components are hydrocarbons of the series $\mathrm{C}_{n} \mathrm{H}_{2 n+2}$, ranging from $n=14$ to 28 , with no predominance and a maximum at $n=17$. Lesser amounts of carboxylic acids (as the methyl esters) and steranes were detected. The acid series, $\mathrm{C}_{n} \mathrm{H}_{2 n} \mathrm{O}_{2}$, ranged from $n=11$ to 24 , with no predominance and a maximum at $n=18$ (cf. Figure 13c). The major steroidal compounds found are of the series $\mathrm{C}_{n} \mathrm{H}_{2 n-6}$, ranging from $n=27$ to 30 and the mass spectra fit the fragmentation patterns of cholestane (Structure III) 
B. R. SIMONEIT, E. S. SCOTT, A. L. BURLINGAME
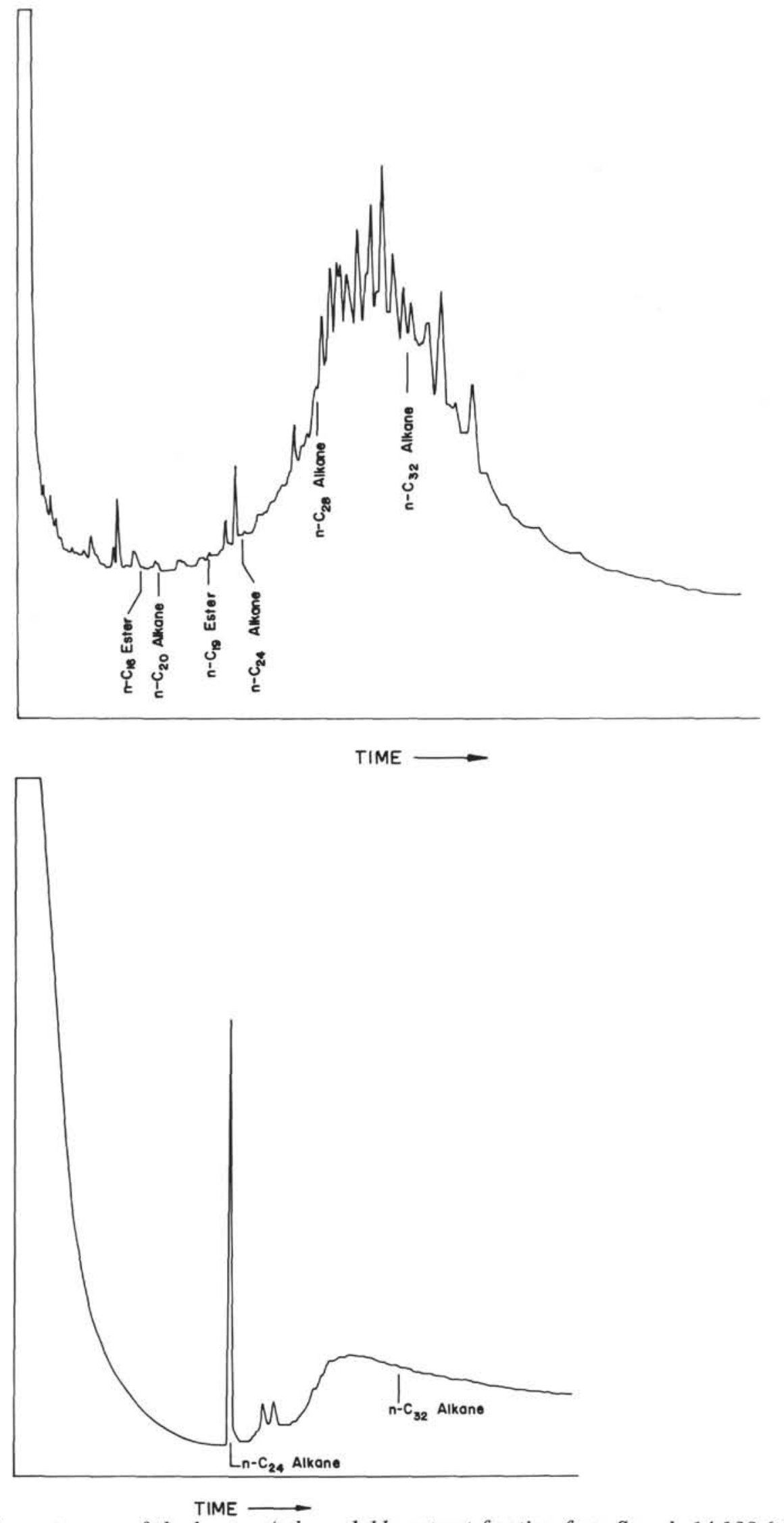

Figure 4a. Gas chromatogram of the heptane/ether-soluble extract fraction from Sample 14-138-6-3 (49-50 cm). Conditions as cited in Figure 1a.

Figure $4 \mathrm{~b}$. Gas chromatogram of the benzene/methanol-soluble extract fraction from Sample 14-138-6-3 $(49-50 \mathrm{~cm})$. Conditions as cited in Figure 1a. 
(cf. scan 320 in Figure 13g), ergostane (Structure IV), and sitostane (Structure V) (cf. scan 349 in Figure 13h) respectively. The scan 141 spectrum (cf. Figure 13f) fits the fragmentation pattern of iso-nonadecane, one of the few iso-alkanes found in these samples. The unknown compound series $\left(\mathrm{C}_{n} \mathrm{H}_{2 n}\right.$ and $\left.\mathrm{C}_{n} \mathrm{H}_{2 n-2}, n=32-35\right)$ found in the Samples 14-144A-5-1 and 14-144A-6-1 were not detected and triterpenoidal compounds were also not present. The major GC peak (at lower retention time in Figure 12a) is again dibutyl azelate, probably from core tube contamination. Phthalate esters were detected in minor amounts only.

The benzene- and methanol-soluble extract fractions of the samples from the Leg 14 Sites 138-2-6 (12-13), 138-6-3 (49-50), 144A-5-1 (114-116), 144-4-2 (20-21), and 144-4-3 (14-15) exhibited one dominant GC component (cf. Figures 1b, 4b 6b,10b and 12b). This peak is found in small quantities in the Core Barrel Extract (Simoneit et al., 1972, Leg 11) and is a major component of the Black Sea core sample $1474(855 \mathrm{~cm}$ level $)$ (Simoneit, in press). A representative GC/MS scan of this compound is shown in Figure 14. From high resolution mass spectrometric data the base peak, $\mathrm{m} / \mathrm{e} 129$, has the composition $\mathrm{C}_{6} \mathrm{H}_{9} \mathrm{O}_{3}$ and $\mathrm{m} / \mathrm{e} 147$ is $\mathrm{C}_{6} \mathrm{H}_{11} \mathrm{O}_{4}$. The compound is dioctyl or di-iso-heptyl 2,3-dimethylsuccinate (Structure $\mathrm{XI}$ ) and its mass spectrometric fragmentation pattern is shown by Structures XI to XV. Synthetic dioctyl

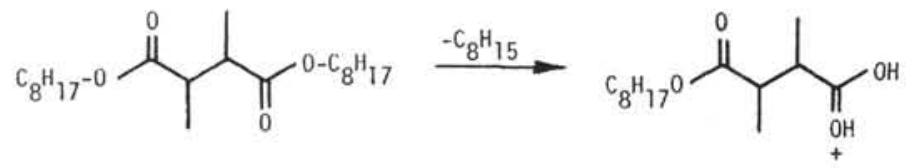

XI $\mathrm{C}_{22} \mathrm{H}_{42} \mathrm{O}_{4}, \mathrm{~m} / \mathrm{e} 370$

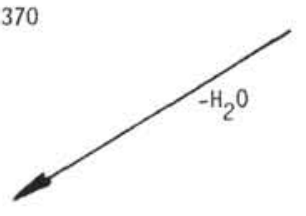

XII $\mathrm{C}_{14} \mathrm{H}_{27} \mathrm{O}_{4}, \mathrm{~m} / \mathrm{e} 259$
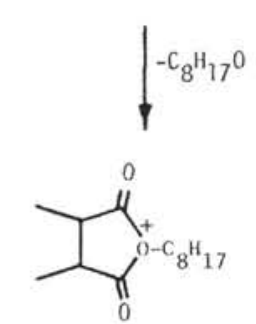

X11 $\mathrm{C}_{14} \mathrm{H}_{25} \mathrm{O}_{3}$, m/e 241
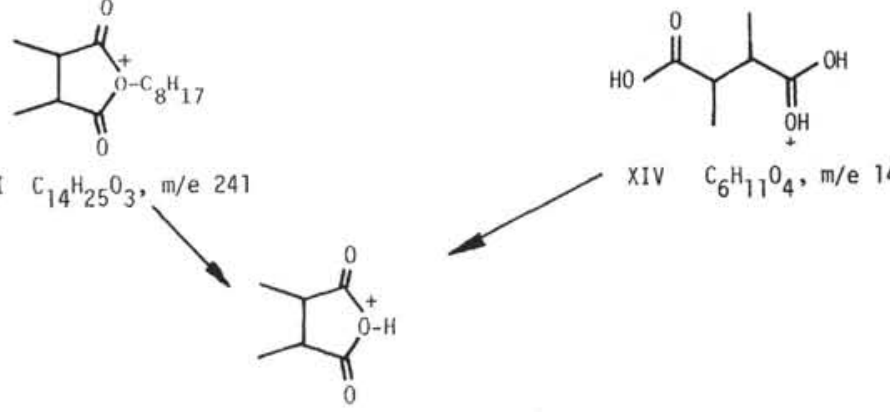

XV $\mathrm{C}_{6} \mathrm{H}_{9} \mathrm{O}_{3}, \mathrm{~m} / \mathrm{e} 129$

2,3-dimethylsuccinate exhibits an identical mass spectrum and the same GC retention time as this major compound in the benzene and methanol extract fractions.

\section{DISCUSSION AND CONCLUSION}

These samples constitute some of the richest (with respect to organic carbon) analyzed to date (Simoneit and Burlingame, 1971a and b, and 1972a and b; Simoneit et al., 1972 , in press, and in preparation). The relatively low amounts of solvent-extractable material indicate that the bulk of the organic carbon in these samples is present as kerogen (cf. Table 1). All the extracts contained significant amounts of carboxylic acid esters, which probably formed during the extraction by clay catalyzed esterification of the acids with solvent methanol. Arpino and Ourisson (1971) observed the same phenomenon during extractions of terrestrial sediments. The amounts of acids in these samples thus derivatized indicate that the clay content still has a significant portion of the organic carbon bound as fatty acid salts (adipocere). It has been well established that clay is a good fatty acid scavenger (Simoneit et al., 1972, in press, and in preparation; Meyers and Quinn, 1971).

The distribution histogram for Sample 14-138-2-6 $(12-13 \mathrm{~cm})$ of Oligocene age is shown in Figure 15a. The alkanes exhibit a strong odd to even predominance and marine alkanes maximizing at $\mathrm{C}_{17}$ are absent. The carboxylic acid distribution maximizes at $\mathrm{C}_{18}$ with an even to odd predominance. The soluble organic matter in this sample appears to be derived mainly from terrigenous sources.

The distribution histogram for Sample 14-138-6-3 $(49-50 \mathrm{~cm})$ of Cretaceous age is shown in Figure 15b. The alkanes and acids exhibit no homolog predominance and maximize in concentration at $\mathrm{C}_{17}$ and $\mathrm{C}_{16}$ respectively. Only steranes consisting mainly of cholestane, ergostane, and sitostane, and the corresponding sterones, are present and are probably all of marine derivation. The narrow distribution envelope of both alkanes and acids (cf. Figure $15 \mathrm{~b})$ substantiates the pure marine source of this sample's soluble organic matter. The geological history of Site 138 indicates that symmetrical cycles of black cherty muds and dolomitic clayey silts were deposited during the Cretaceous. The origin of these 20 to $30 \mathrm{~cm}$ thick sedimentary cycles may possibly indicate a fluctuating chemical environment (Hayes, Pimm et al., 1972). Sample 14-138-6-3 (49-50 cm) was thus probably sedimented during a productive marine plankton bloom.

The distribution histograms of the Site 144 samples, all of Cretaceous age, are shown in Figure 16. Sample 14-144A-5-1 (114-116 cm) exhibits no homolog predominance for the alkanes and acids and they maximize at $\mathrm{C}_{17}$ and $\mathrm{C}_{16}$ respectively. Again, the narrow distribution envelope of both the alkanes and acids (cf. Figure 16a) indicates essentially a marine source of the soluble organic matter. Sample 14-144A-6-1 (100-101 cm) (cf. Figure 16b) contains a low amount of alkanes, maximizing at $\mathrm{C}_{17}$, with a slight odd to even predominance and extending to $\mathrm{C}_{30}$. The acids exhibit a narrow envelope maximizing at $\mathrm{C}_{16}$ and the major components are a series of probably cyclic hydrocarbons maximizing at $\mathrm{C}_{34}$ (cf. Figure 16b). The source of this soluble organic matter appears to be marine, and it may have had a major contribution from an unknown species analogous to the present day alga Botryococcus braunii, which contains various $\mathrm{C}_{34}$ hydrocarbons at one stage of its life cycle (Maxwell et al., 1968). 


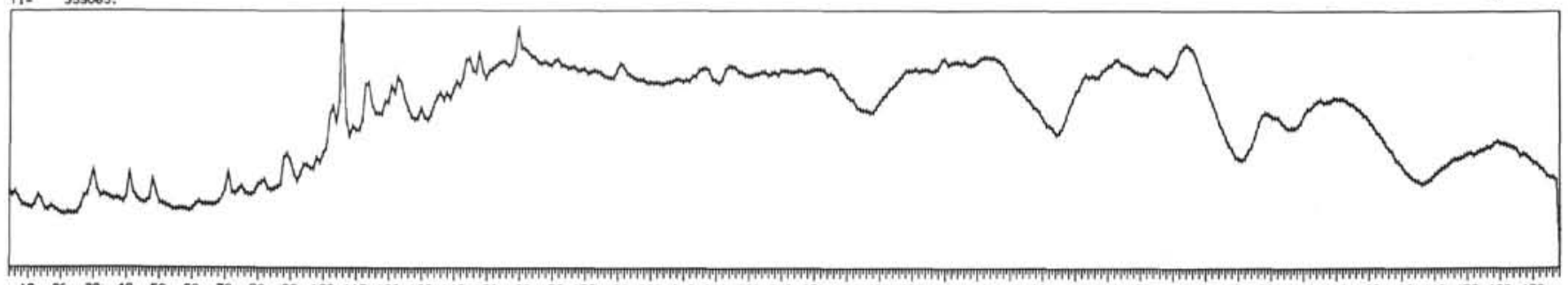

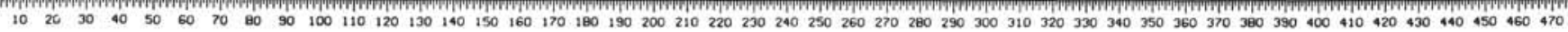

b

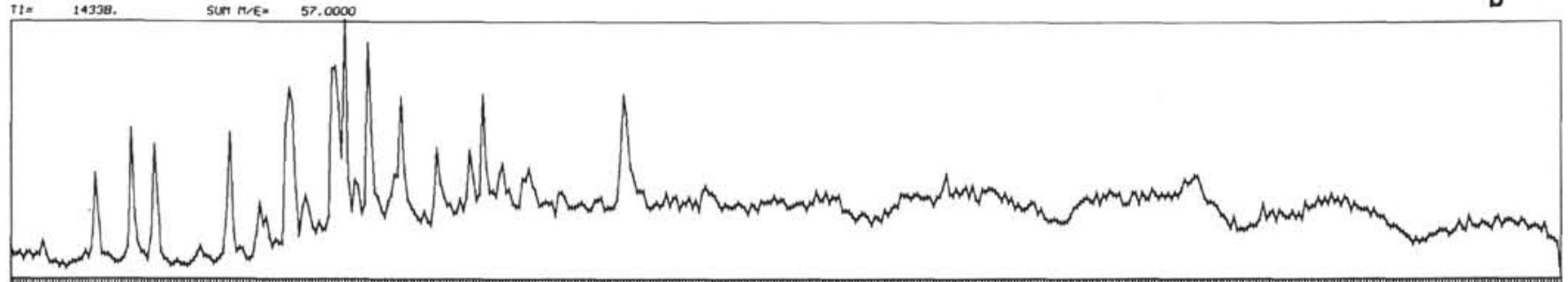

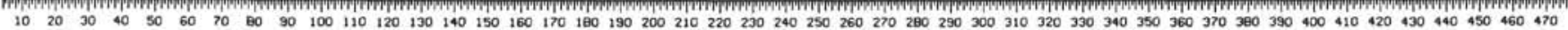

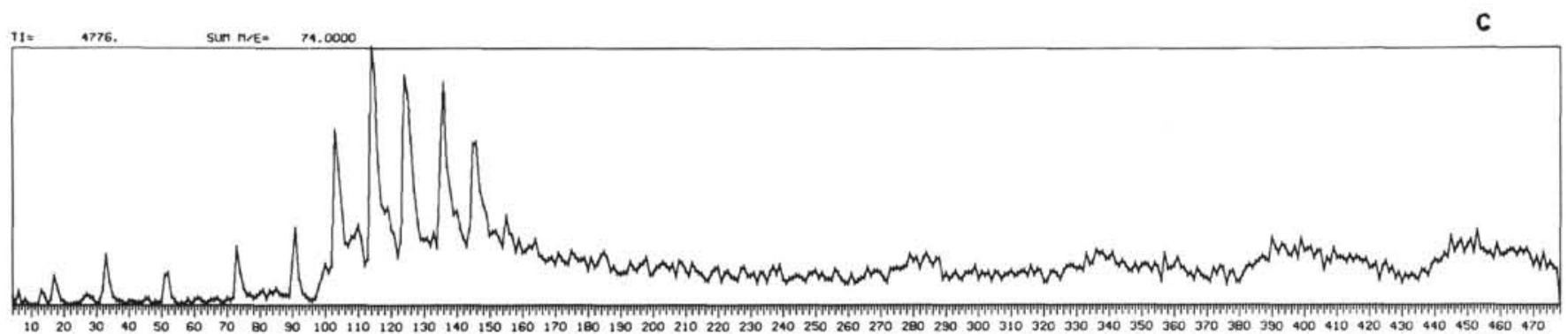

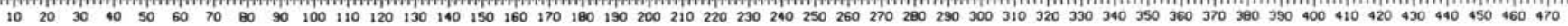

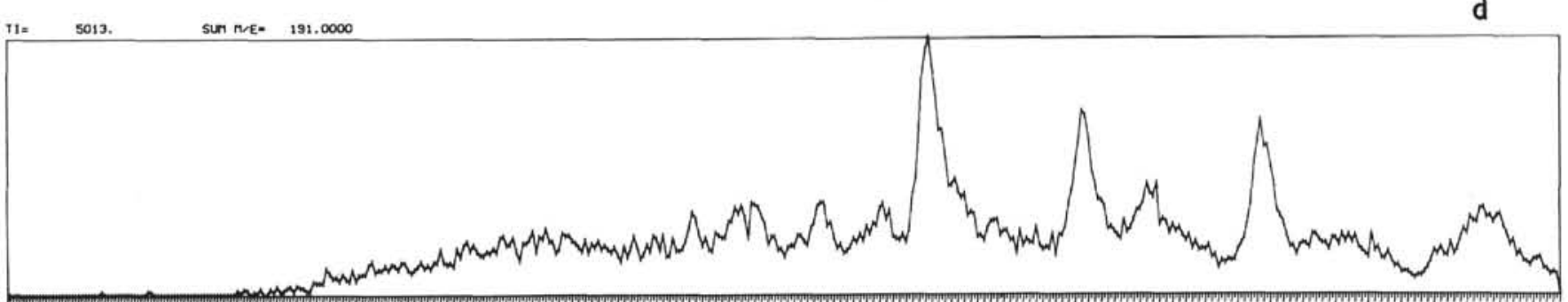

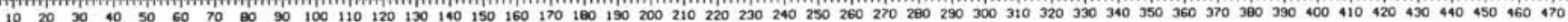

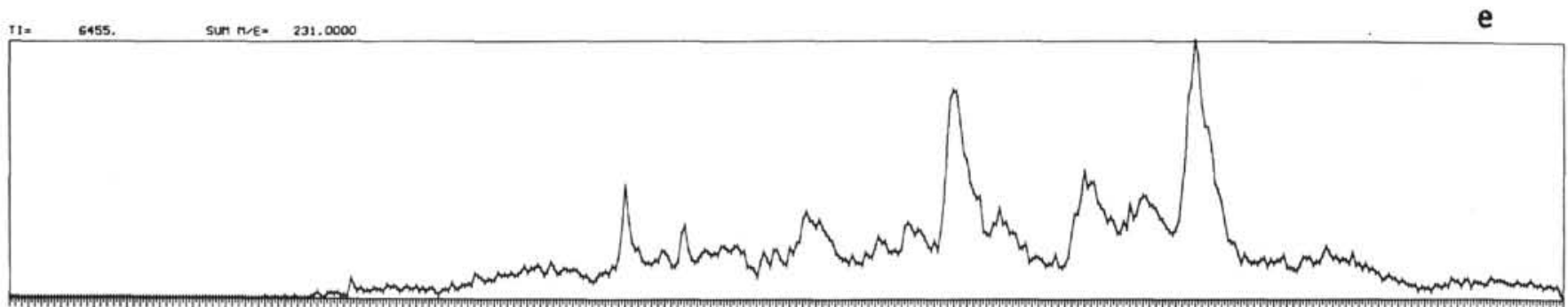

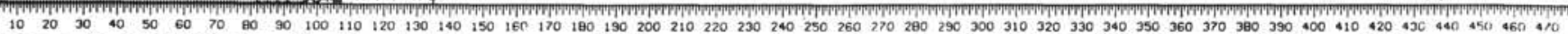

Figure 5. GC/MS data for the total heptane-soluble extract from Sample 14-138-6-3 (49-50 cm). (GC conditions as cited in

Figure 1a).

a) total ionization sum plot.

b) $\mathrm{m} / \mathrm{e} 57$ sum plot.

c) $\mathrm{m} / \mathrm{e} 74$ sum plot.

d) $\mathrm{m} / \mathrm{e} 191$ sum plot.

e) $\mathrm{m} / \mathrm{e} 231$ sum plot.

f) mass spectrum scan 106 (unknown, M-250).

g) mass spectrum scan 291 (cholestanone).

h) mass spectrum scan 364 (stigmastanone). 

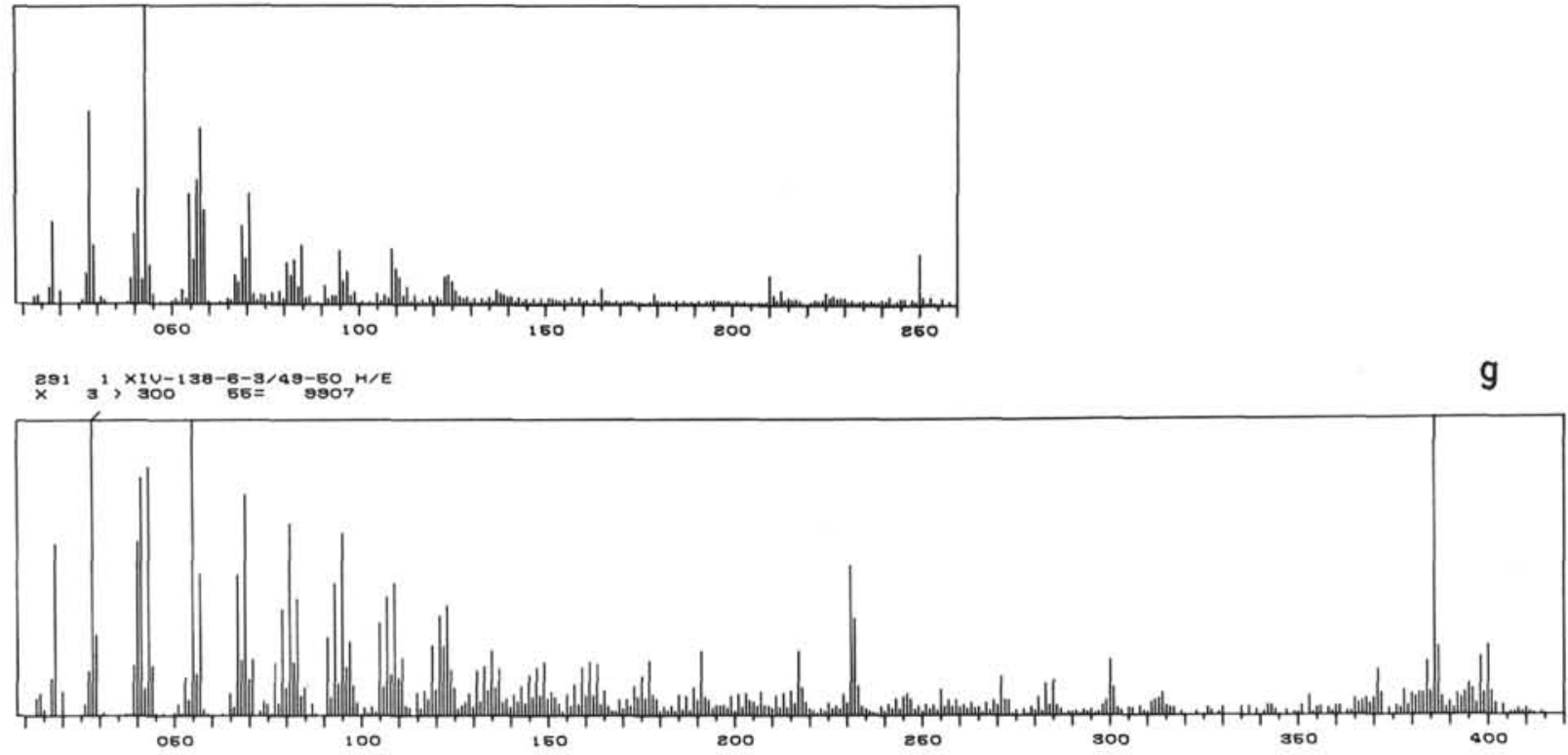

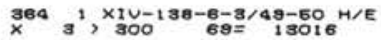

h

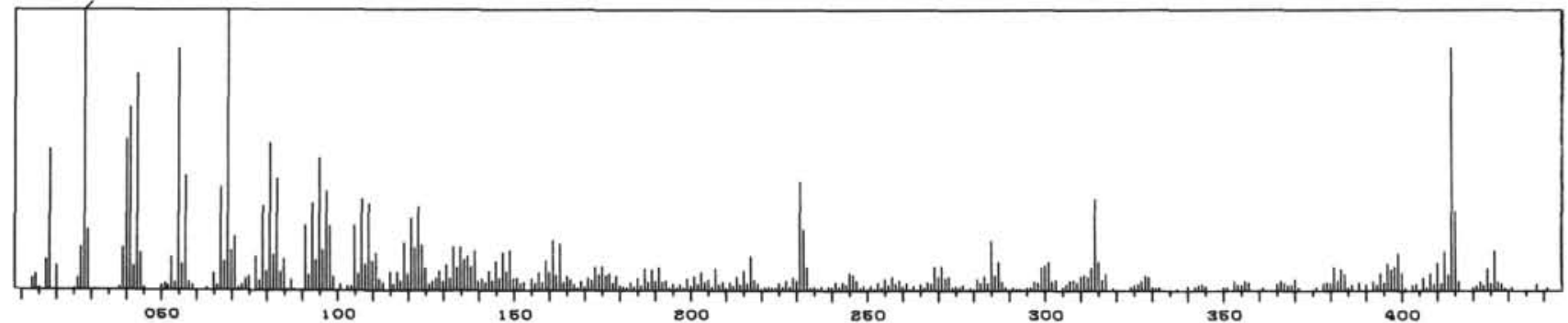

Figure 5. (Continued). 
B. R. SIMONEIT, E. S. SCOTT, A. L. BURLINGAME

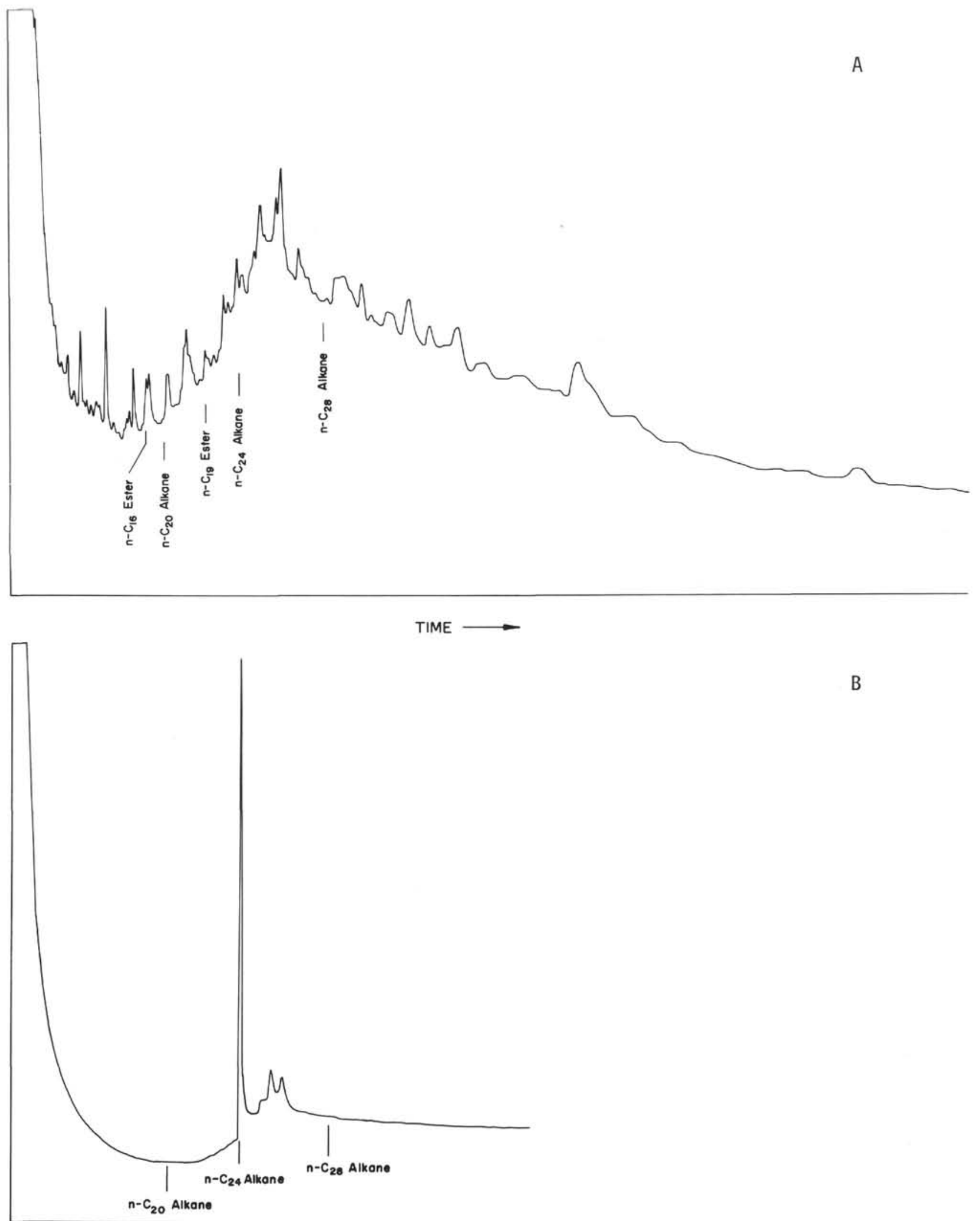

TIME

Figure 6a. Gas chromatogram of the heptane/ether-soluble extract fraction from Sample 14-144A-5-1 (114-116 cm). Conditions as cited in Figure 1a, except column length is $10 \mathrm{ft}$.

Figure 6b. Gas chromatogram of the benzene/methanol-soluble extract fraction from Sample 14-144A-5-1 (114-116 cm). Conditions as cited in Figure $4 a$. 
TABLE 4

Major Components of the Heptane-Ether Soluble Extracts from the Core Samples of DSDP Site 144, Determined by GC/MS

\begin{tabular}{|c|c|c|c|c|c|}
\hline \multirow[b]{3}{*}{ Compound Name } & & & \multicolumn{3}{|c|}{ Sample } \\
\hline & & & $\begin{array}{l}14-144 \mathrm{~A}-5-1 \\
(114-116 \mathrm{~cm})\end{array}$ & $\begin{array}{l}14-144 \mathrm{~A}-6-1 \\
(100-101 \mathrm{~cm})\end{array}$ & $\begin{array}{l}14-144-4-3 \\
(14-15 \mathrm{~cm})\end{array}$ \\
\hline & \multicolumn{2}{|c|}{$\begin{array}{l}\text { Composition and } \\
\text { Molecular Weight }\end{array}$} & $\begin{array}{l}\text { Spectrum Scan No. } \\
\text { (cf. Fig. 7a) }\end{array}$ & $\begin{array}{l}\text { Spectrum Scan No. } \\
\text { (cf. Fig. 9a) }\end{array}$ & $\begin{array}{l}\text { Spectrum Scan No. } \\
\text { (cf. Fig. 13a) }\end{array}$ \\
\hline iso-Tetradecane & $\mathrm{C}_{14} \mathrm{H}_{30}$ & 198 & n.d. & 45 & n.d. \\
\hline Methyl $n$-undecanoate & $\mathrm{C}_{12} \mathrm{H}_{24} \mathrm{O}_{2}$ & 200 & n.d. & n.d. & 49 \\
\hline Methyl laurate & $\mathrm{C}_{13} \mathrm{H}_{26} \mathrm{O}_{2}$ & 214 & n.d. & n.d. & 66 \\
\hline Pentadecane & $\mathrm{C}_{15} \mathrm{H}_{32}$ & 212 & 49 & n.d. & n.d. \\
\hline Diethyl phthalate ${ }^{b}$ & $\mathrm{C}_{12} \mathrm{H}_{14} \mathrm{O}_{4}$ & 222 & 61 & n.d. & 75 \\
\hline Methyl $n$-tridecanoate & $\mathrm{C}_{14} \mathrm{H}_{28} \mathrm{O}_{2}$ & 228 & n.d. & n.d. & 84 \\
\hline Hexadecane & $\mathrm{C}_{16} \mathrm{H}_{34}$ & 226 & 67 & 62 & 78 \\
\hline Pristane & $\mathrm{C}_{19} \mathrm{H}_{40}$ & 268 & n.d. & n.d. & 98 \\
\hline Heptadecane & $\mathrm{C}_{17} \mathrm{H}_{36}$ & 240 & 82 & 87 & 100 \\
\hline Methyl myristate & $\mathrm{C}_{15} \mathrm{H}_{30} \mathrm{O}_{2}$ & 242 & 83 & 88 & 102 \\
\hline $\begin{array}{l}\text { Unknown } \\
n \text {-Octadecane }\end{array}$ & $\mathrm{C}_{18} \overline{\mathrm{H}}_{38}$ & $\begin{array}{l}266 \\
254\end{array}$ & n.d. & $\begin{array}{l}\text { n.d. } \\
102\end{array}$ & $\begin{array}{l}108 \\
123\end{array}$ \\
\hline Methyl $n$-pentadecanoate & $\mathrm{C}_{16} \mathrm{H}_{32} \mathrm{O}_{2}$ & 256 & 96 & 115 & 126 \\
\hline $\begin{array}{l}\text { Unknown } \\
\text { iso-Nonadecane }\end{array}$ & $\mathrm{C}_{19} \overline{\mathrm{H}}_{40}$ & $\begin{array}{l}250 \\
268\end{array}$ & $\begin{array}{r}99 \\
\text { n.d. }\end{array}$ & $\begin{array}{l}120 \\
\text { n.d. }\end{array}$ & $\begin{array}{l}\text { n.d. } \\
141\end{array}$ \\
\hline $\begin{array}{l}\text { Unknown } \\
n \text {-Nonadecane }\end{array}$ & $\mathrm{C}_{19} \overline{\mathrm{H}}_{40}$ & $\begin{array}{l}306 \\
268\end{array}$ & $\begin{array}{l}\text { n.d. } \\
109\end{array}$ & $\begin{array}{l}128 \\
133\end{array}$ & $\begin{array}{l}\text { n.d. } \\
153\end{array}$ \\
\hline Methyl palmitate & $\mathrm{C}_{17} \mathrm{H}_{34} \mathrm{O}_{2}$ & 270 & 110 & 135 & 157 \\
\hline Dibutyl phthalate ${ }^{b}$ & $\mathrm{C}_{16} \mathrm{H}_{22} \mathrm{O}_{4}$ & 278 & 112 & n.d. & 159 \\
\hline$n$-Eicosane & $\mathrm{C}_{20} \mathrm{H}_{42}$ & 282 & 127 & 153 & 173 \\
\hline Methyl margarate & $\mathrm{C}_{18} \mathrm{H}_{36} \mathrm{O}_{2}$ & 284 & 128 & 154 & 175 \\
\hline Dibutyl azelate & $\mathrm{C}_{17} \mathrm{H}_{32} \mathrm{O}_{4}$ & 300 & n.d. & 159 & 181 \\
\hline Methyl stearate & $\mathrm{C}_{19} \mathrm{H}_{38} \mathrm{O}_{2}$ & 298 & 143 & 172 & 188 \\
\hline Docosene & $\mathrm{C}_{22} \mathrm{H}_{44}$ & 308 & n.d. & 172 & n.d. \\
\hline$n$-Heneicosane & $\mathrm{C}_{21} \mathrm{H}_{44}$ & 296 & 147 & 171 & 187 \\
\hline Dibutyl sebacate ${ }^{a}$ & $\mathrm{C}_{18} \mathrm{H}_{34} \mathrm{O}_{4}$ & 314 & n.d. & 177 & 192 \\
\hline$n$-Docosane & $\mathrm{C}_{22} \mathrm{H}_{46}$ & 310 & n.d. & 186 & 200 \\
\hline Methyl nonadecanoate & $\mathrm{C}_{20} \mathrm{H}_{40} \mathrm{O}_{2}$ & 312 & 157 & 188 & 201 \\
\hline Dibutyl hendecanedioate $^{a}$ & $\mathrm{C}_{19} \mathrm{H}_{36} \mathrm{O}_{4}$ & 328 & n.d. & 192 & n.d. \\
\hline Methyl arachidate & $\mathrm{C}_{21} \mathrm{H}_{42} \mathrm{O}_{2}$ & 326 & 171 & 201 & 217 \\
\hline$n$-Tetracosane & $\mathrm{C}_{24} \mathrm{H}_{50}$ & 338 & n.d. & 213 & 232 \\
\hline Methyl heneicosanoate & $\mathrm{C}_{22} \mathrm{H}_{44} \mathrm{O}_{2}$ & 340 & 183 & 214 & 234 \\
\hline$n$-Pentacosane & $\mathrm{C}_{25} \mathrm{H}_{52}$ & 352 & n.d. & 227 & 252 \\
\hline $\begin{array}{l}\text { Unknown } \\
\text { Unknown }\end{array}$ & - & $\begin{array}{l}378 \\
444\end{array}$ & $\begin{array}{l}\text { n.d. } \\
191\end{array}$ & $\begin{array}{l}228 \\
228\end{array}$ & $\begin{array}{l}\text { n.d. } \\
\text { n.d. }\end{array}$ \\
\hline Methyl behenate & $\mathrm{C}_{23} \mathrm{H}_{46} \mathrm{O}_{2}$ & 354 & 197 & 229 & 255 \\
\hline Hexacosane & $\mathrm{C}_{26} \mathrm{H}_{54}$ & 366 & n.d. & 245 & 277 \\
\hline $\begin{array}{l}\text { Unknown } \\
\text { Methyl tricosanoate }\end{array}$ & $\mathrm{C}_{24} \overline{\mathrm{H}}_{48} \mathrm{O}_{2}$ & $\begin{array}{l}446 \\
368\end{array}$ & $\begin{array}{l}\text { n.d. } \\
\text { n.d. }\end{array}$ & $\begin{array}{l}246 \\
247\end{array}$ & $\begin{array}{l}\text { n,d. } \\
282\end{array}$ \\
\hline Heptacosane & $\mathrm{C}_{27} \mathrm{H}_{56}$ & 380 & n.d. & 264 & 297 \\
\hline Methyl lignocerate & $\mathrm{C}_{25} \mathrm{H}_{50} \mathrm{O}_{2}$ & 382 & n.d. & 268 & 308 \\
\hline Unknown & - & 460 & n.d. & 277 & n.d. \\
\hline
\end{tabular}


TABLE 4 - Continued

\begin{tabular}{|c|c|c|c|c|c|}
\hline \multirow[b]{3}{*}{ Compound Name } & & & \multicolumn{3}{|c|}{ Sample } \\
\hline & & & $\begin{array}{l}14-144 \mathrm{~A}-5-1 \\
(114-116 \mathrm{~cm})\end{array}$ & $\begin{array}{l}14-144 \mathrm{~A}-6-1 \\
(100-101 \mathrm{~cm})\end{array}$ & $\begin{array}{l}14-144-4-3 \\
(14-15 \mathrm{~cm})\end{array}$ \\
\hline & \multicolumn{2}{|c|}{$\begin{array}{l}\text { Composition and } \\
\text { Molecular Weight }\end{array}$} & $\begin{array}{l}\text { Spectrum Scan No. } \\
\text { (cf. Fig. 7a) }\end{array}$ & $\begin{array}{l}\text { Spectrum Scan No. } \\
\text { (cf. Fig. 9a) }\end{array}$ & $\begin{array}{l}\text { Spectrum Scan No. } \\
\text { (cf. Fig. 13a) }\end{array}$ \\
\hline Octacosane & $\mathrm{C}_{28} \mathrm{H}_{58}$ & 394 & n.d. & 283 & 318 \\
\hline $\begin{array}{l}\text { Unknown } \\
\text { Unknown }\end{array}$ & $\begin{array}{l}20 \\
- \\
-\end{array}$ & $\begin{array}{l}476 \\
474\end{array}$ & $\begin{array}{l}211 \\
211\end{array}$ & $\begin{array}{l}306 \\
314\end{array}$ & $\begin{array}{l}\text { n.d. } \\
\text { n.d. }\end{array}$ \\
\hline Cholestane & $\mathrm{C}_{27} \mathrm{H}_{48}$ & 372 & n.d. & 314 & 320 \\
\hline Ergostane & $\mathrm{C}_{28} \mathrm{H}_{50}$ & 386 & n.d. & n.d. & 333 \\
\hline Sterane & $\mathrm{C}_{28} \mathrm{H}_{48}$ & 384 & n.d. & n.d. & 333 \\
\hline Triterpane & $\mathrm{C}_{30} \mathrm{H}_{48}$ & 408 & 225 & n.d. & n.d. \\
\hline Stigmastane & $\mathrm{C}_{29} \mathrm{H}_{52}$ & 400 & 225 & n.d. & 349 \\
\hline Triterpane & $\mathrm{C}_{30} \mathrm{H}_{54} \mathrm{O}$ & 430 & 240 & n.d. & n.d. \\
\hline Unknown & - & 490 & n.d. & 321 & n.d. \\
\hline Unknown & - & 488 & n.d. & 336 & n.d. \\
\hline
\end{tabular}

a Probably core tube contamination.

brobably bagging contamination.

n.d. - Not detected. 


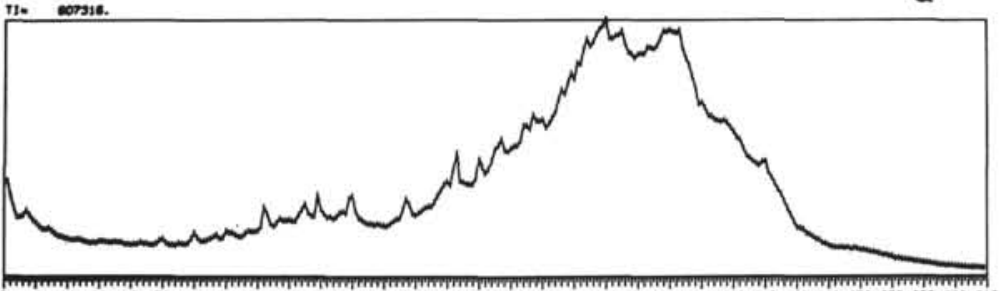

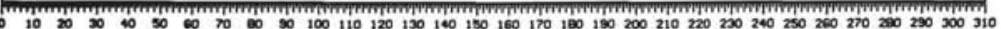
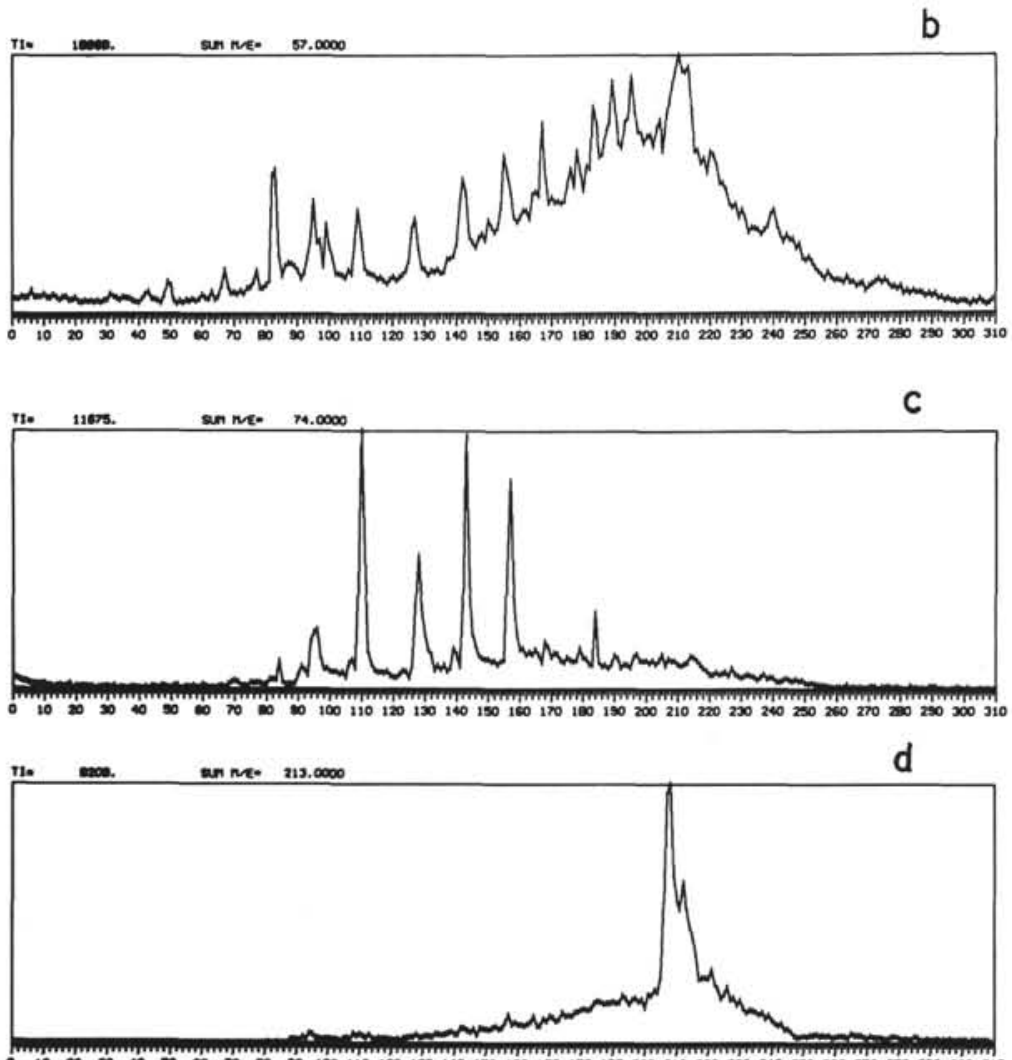

- 10 -

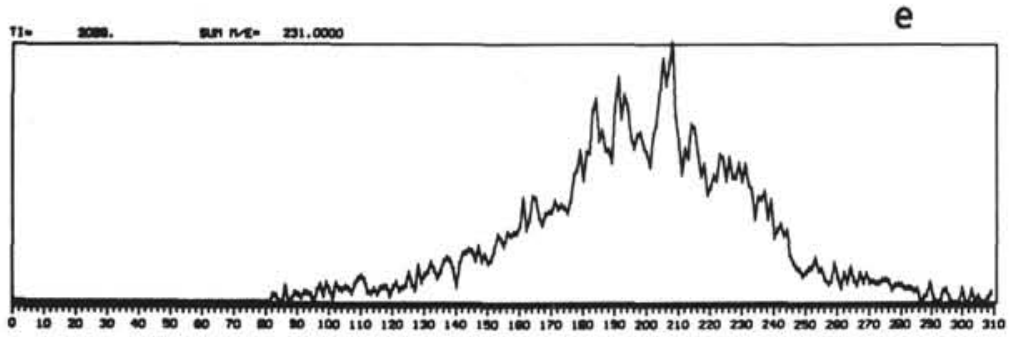

Figure 7. GC/MS data for the total heptane-soluble extract from Sample 14-144A-5-1 (114-116 cm). (GC conditions as cited in Figure 1a).
a) total ionization sum plot.
b) $\mathrm{m} / \mathrm{e} 57 \mathrm{sum}$ plot.
c) $\mathrm{m} / \mathrm{e} 74 \mathrm{sum}$ plot.
d) $\mathrm{m} / \mathrm{e} 213$ sum plot.
e) $\mathrm{m} / \mathrm{e} 231$ sum plot. 
B. R. SIMONEIT, E. S. SCOTT, A. L. BURLINGAME

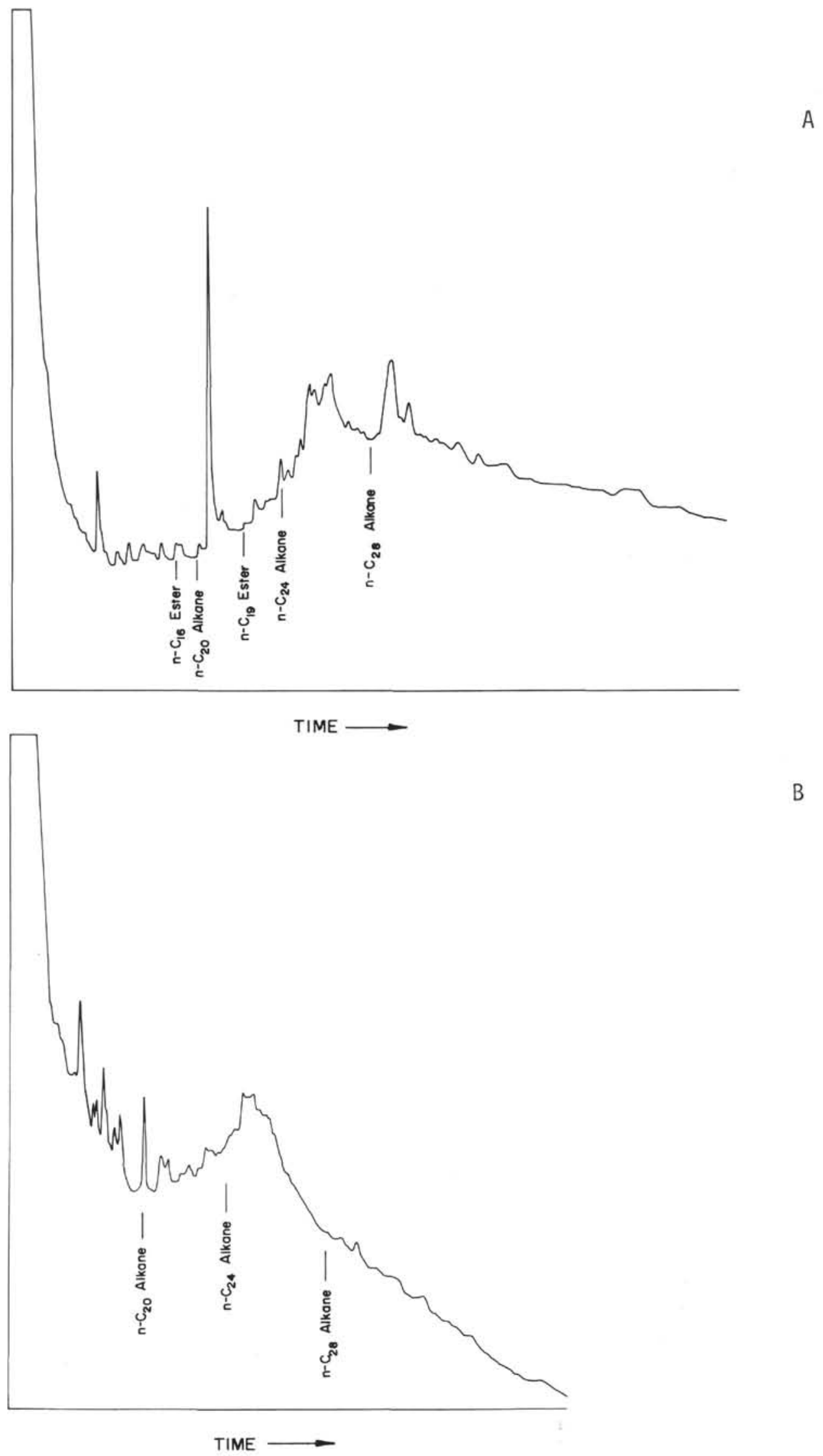

Figure 8a. Gas chromatogram of the heptane/ether-soluble extract fraction from Sample 14-144A-6-1 (100-101 cm). Conditions as cited in Figure $4 a$.

Figure 8b. Gas chromatogram of the benzene/methanol-soluble extract fraction from Sample 14-144A-6-1 (100-101 cm). Conditions as cited in Figure $4 a$. 


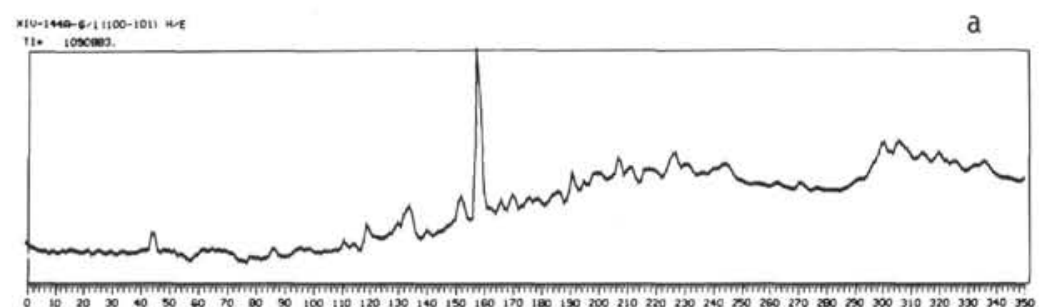

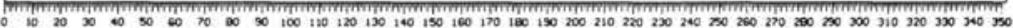
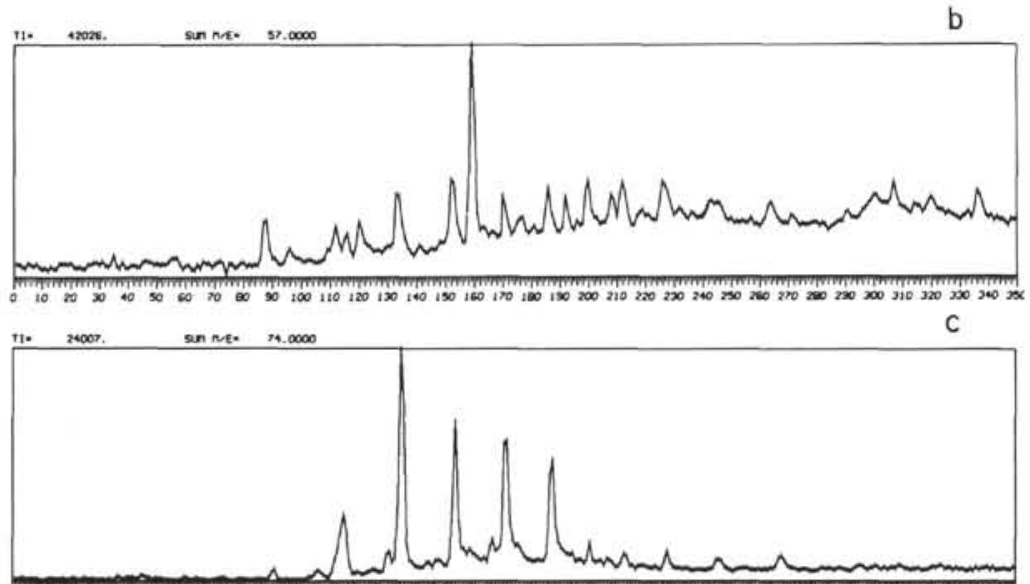

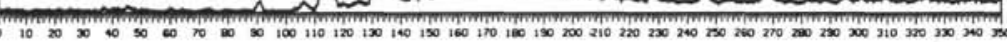
1. sose. $\sin m \cdot \operatorname{nos} .0000$

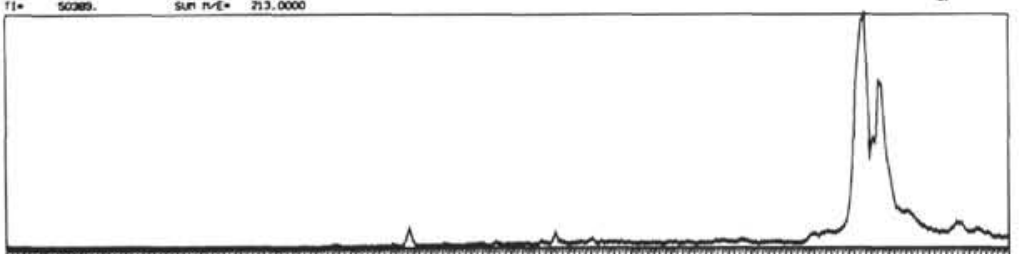

10.

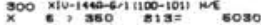

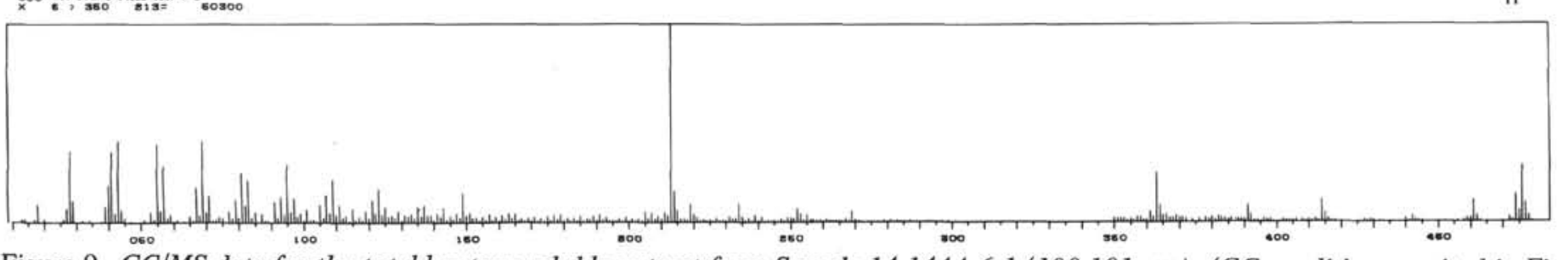

Figure 9. GC/MS data for the total heptane-soluble extract from Sample 14-144A-6-1 (100-101 cm). (GC conditions as cited in Figure 1a).

a) total ionization sum plot. $\quad$ e) $\mathrm{m} / \mathrm{e} 231$ sum plot.

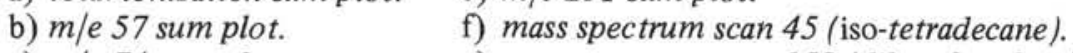

c) m/e 74 sum plot. $\quad$ g) mass spectrum scan 159 (dibutyl azelate)

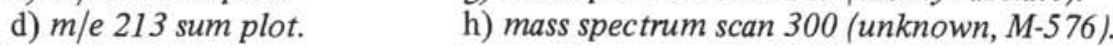

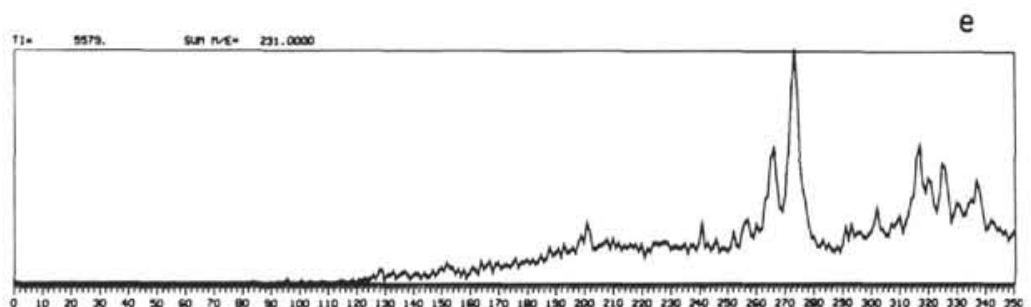

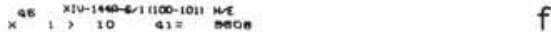

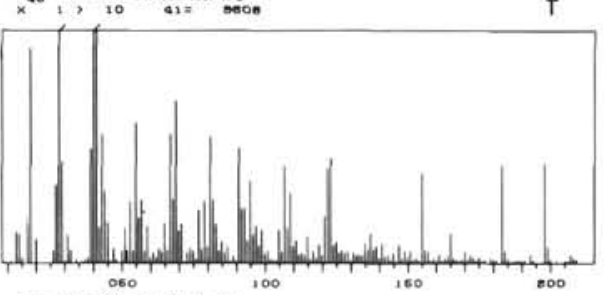

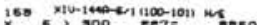

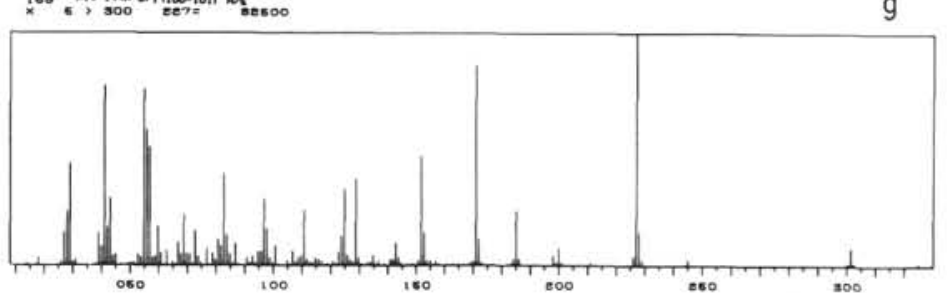



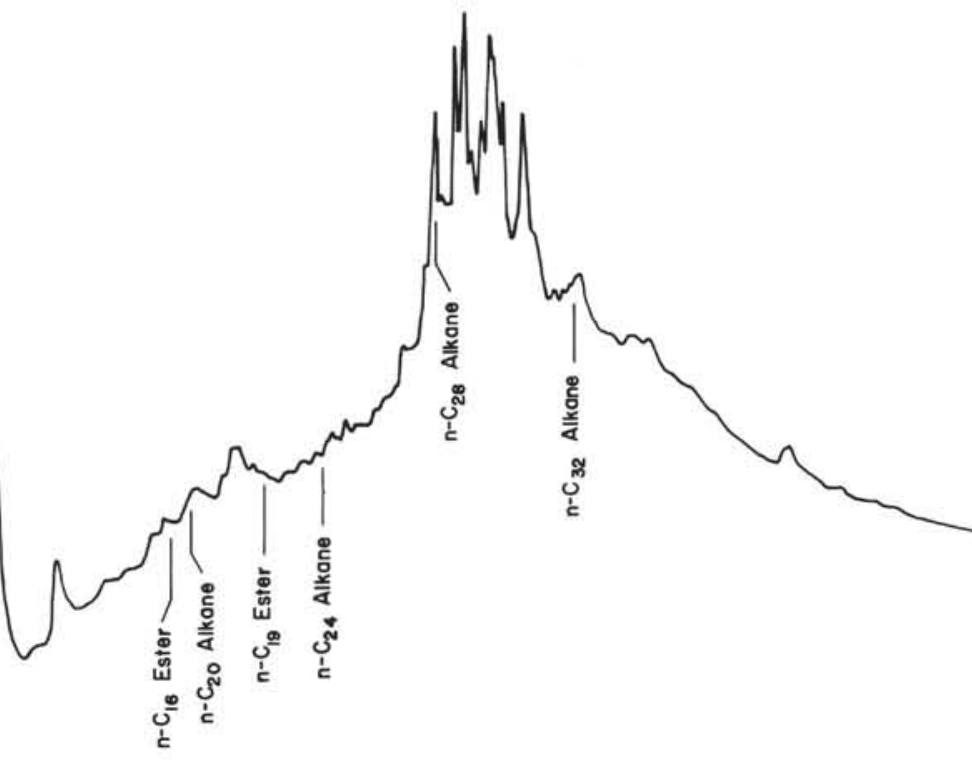

TIME

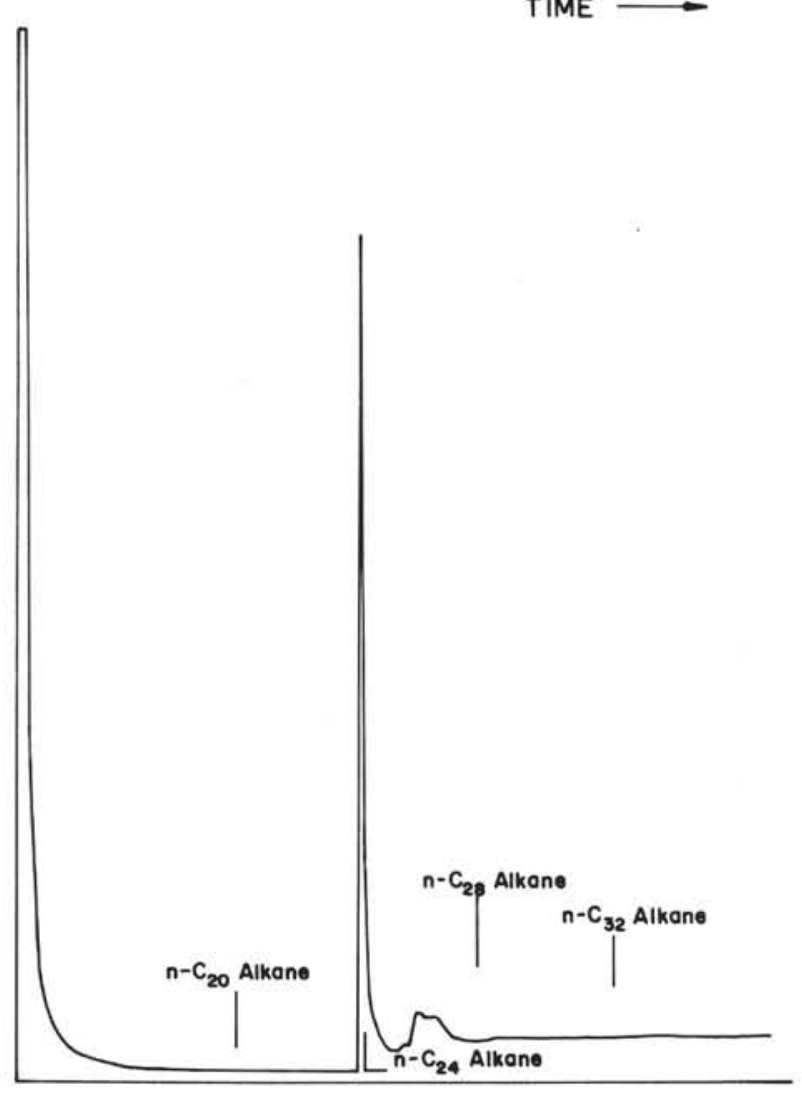

TIME

Figure 10a. Gas chromatogram of the heptane/ether-soluble extract fraction from Sample 14-144-4-2 $(20-21 \mathrm{~cm})$. Conditions as cited in Figure 1a.

Figure 10b. Gas chromatogram of the toluene/methanol-soluble extract fraction from Sample 14-144-4-2 (20-21 cm). Conditions as cited in Figure 1 . 

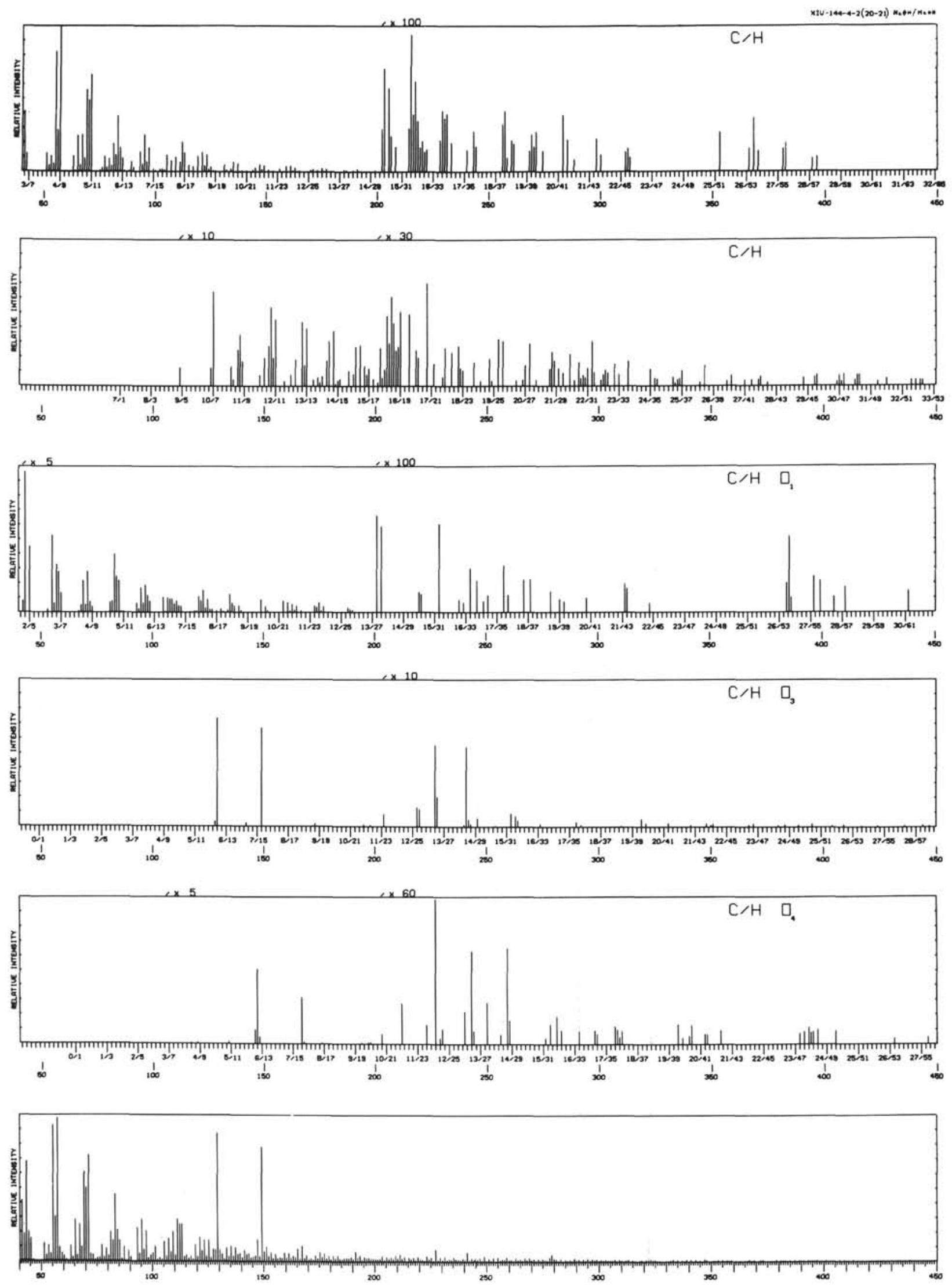

Figure 11. Partial high resolution mass spectrometric data for the toluene-and methanol-soluble fraction from the exhaustive extract of Sample 14-144-4-2 (20-21 cm). 
B. R. SIMONEIT, E. S. SCOTT, A. L. BURLINGAME

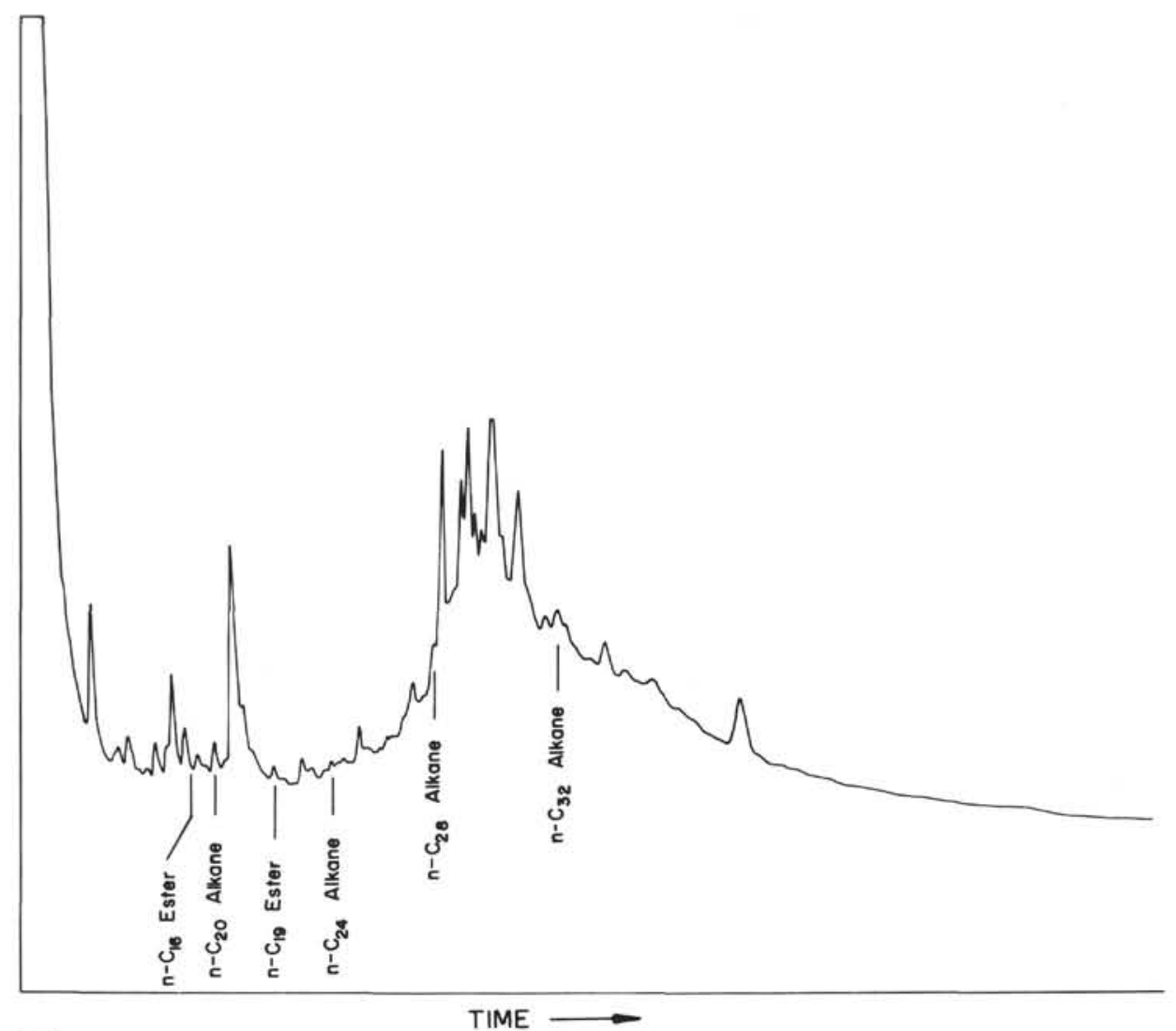

A

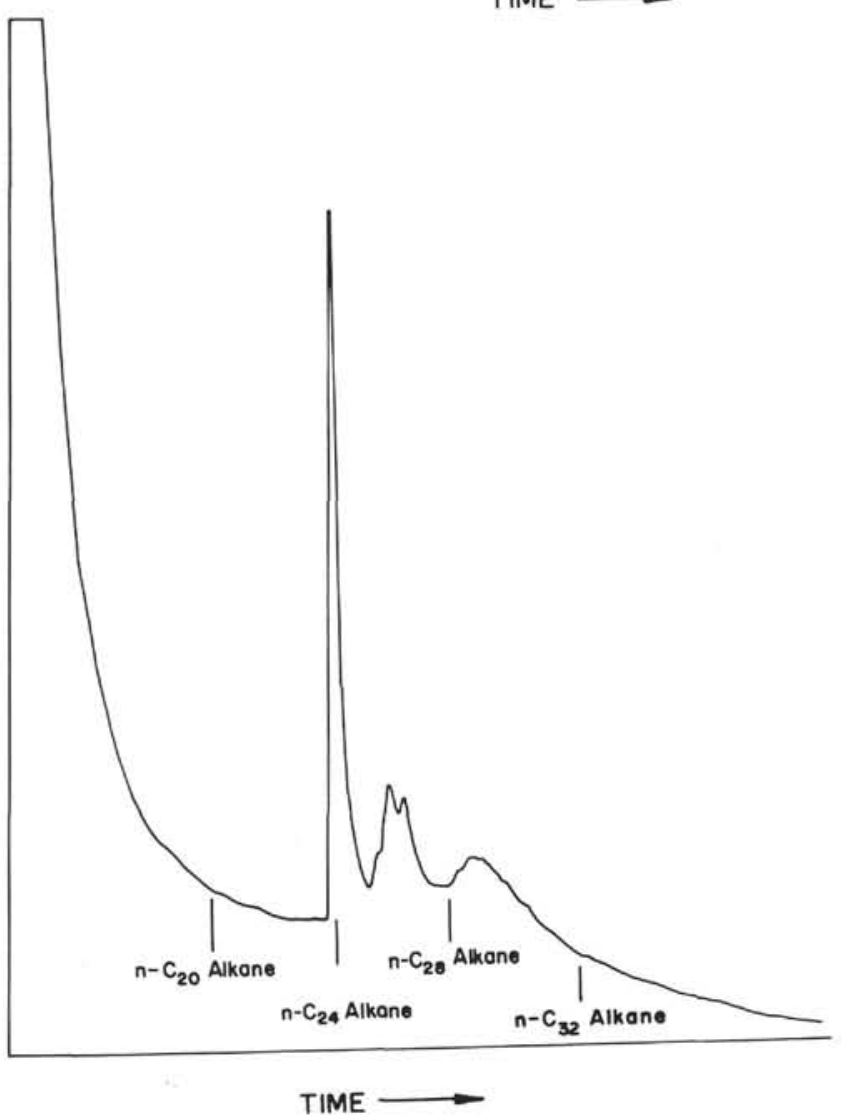

Figure 12a. Gas chromatogram of the heptane/ether-soluble extract fraction from Sample 14-144-4-3 (14-15 cm). Conditions as cited in Figure la.

Figure 12b. Gas chromatogram of the benzene/methanol-soluble extract fraction from Sample 14-144-4-3 $(14-15 \mathrm{~cm})$. Conditions as cited in Figure 1a. 


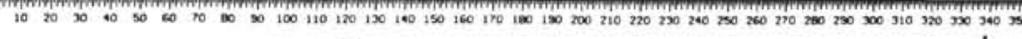
11. 10012 .
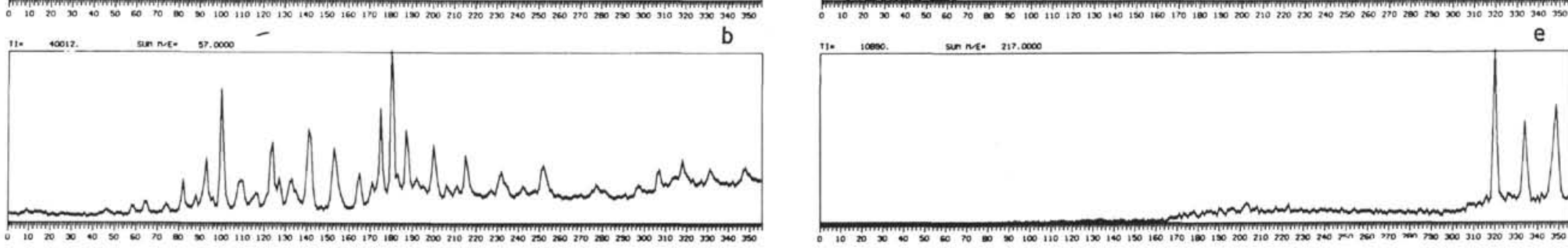
I.

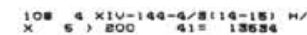

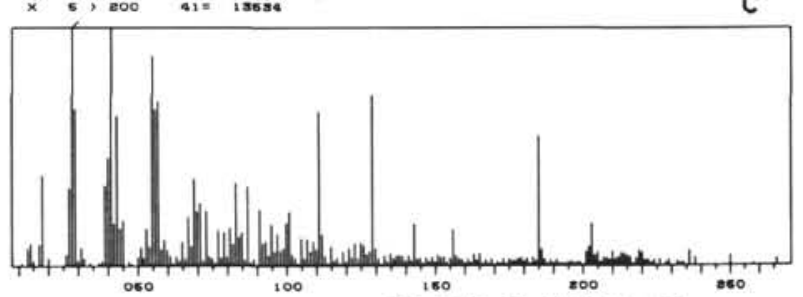

$320,4 \times 14-140-438194-152$, w/E

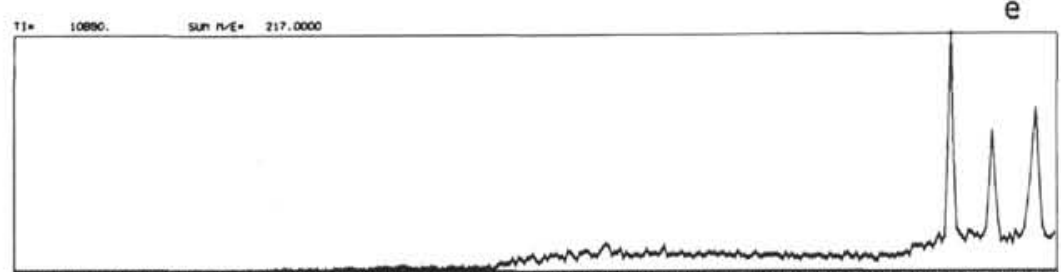

(4)

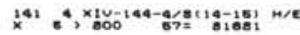
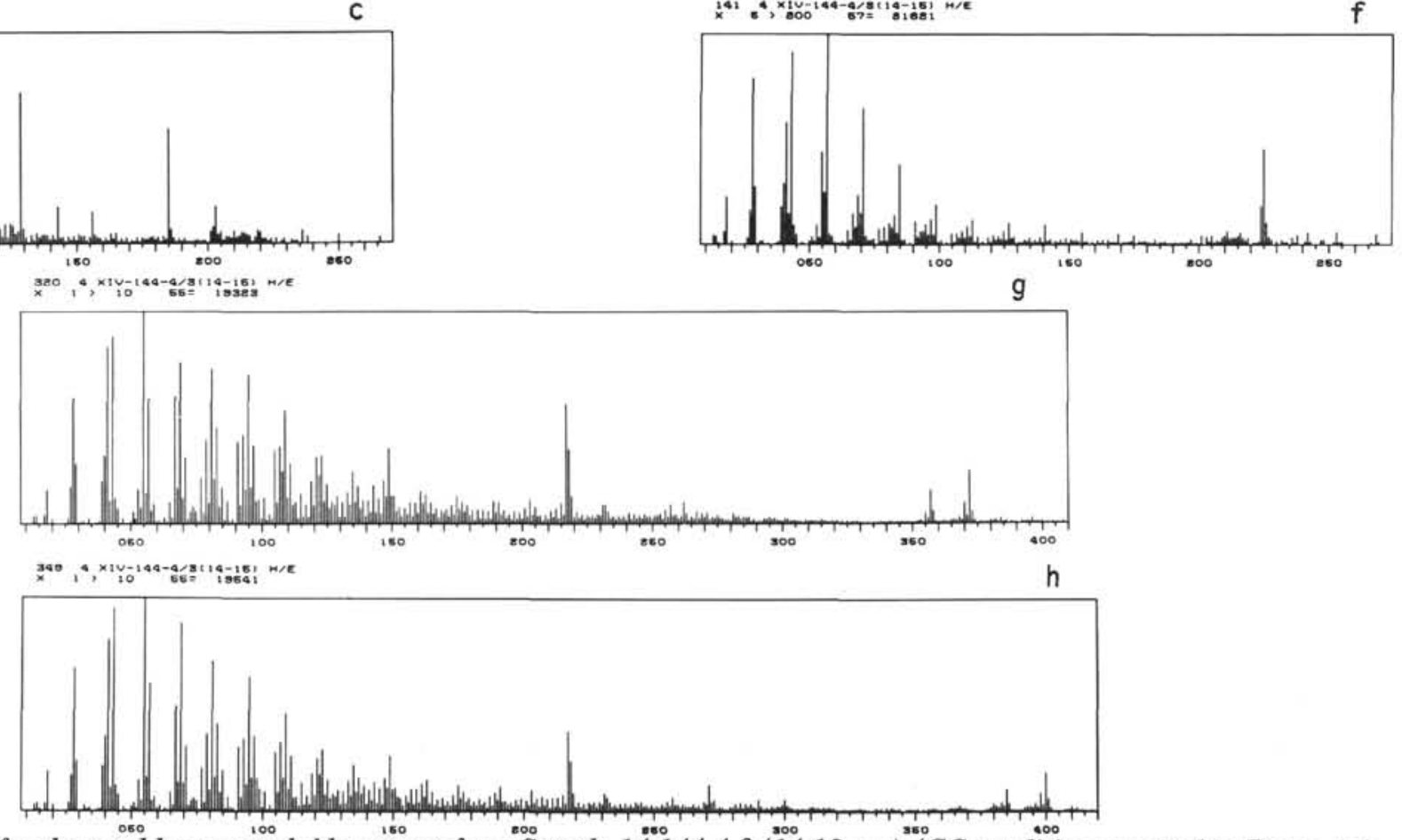

Figure 13. GC/MS data for the total heptane-soluble extract from Sample 14-144-4-3 (14-15 cm). (GC conditions as cited in Figure 1a).

a) total ionization sum plot.

e) mass spectrum scan 108 (unknown, M-266).

b) $\mathrm{m} / \mathrm{e} 57 \mathrm{sum}$ plot.

c) $\mathrm{m} / \mathrm{e} 74$ sum plot.

f) mass spectrum scan 141 (iso-nonadecane).

d) $\mathrm{m} / \mathrm{e} 217$ sum plot.

h) mass spectrum scan 349 (stigmastane). 


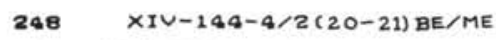

$\times \quad 5>210 \quad 129=23481$

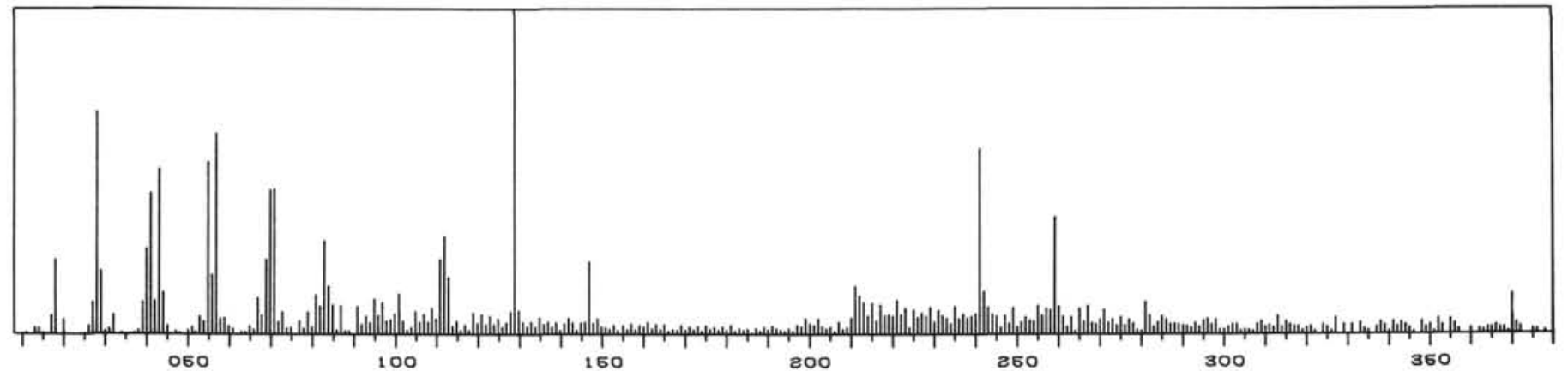

Figure 14. GC/MS scan of the major peak in the benzene/methanol-soluble fraction from Sample 14-144-4-2 (20-21 cm)scan 248 (probably dioctyl 2,3-dimethylsuccinate).

a

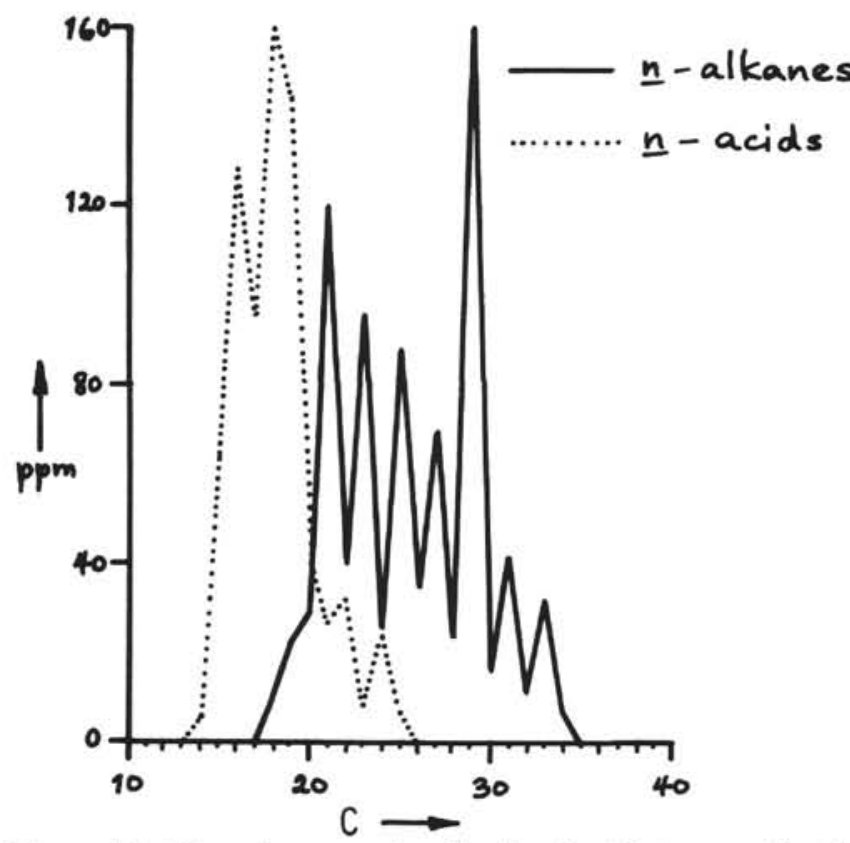

b

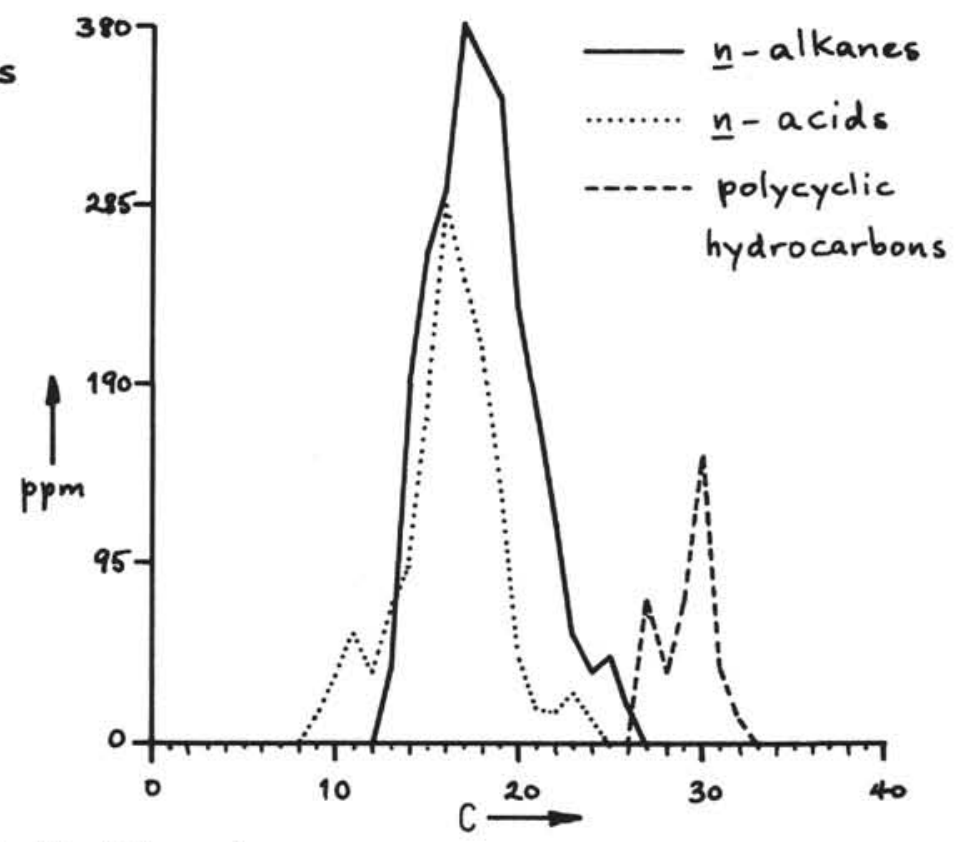

Figure 15. Homologous series distribution histograms for the Site 138 samples.

a) $14-138-2-6(12-13 \mathrm{~cm})$.

b) $14-138-6-3(49-50 \mathrm{~cm})$. 
PRELIMINARY ORGANIC ANALYSES

a

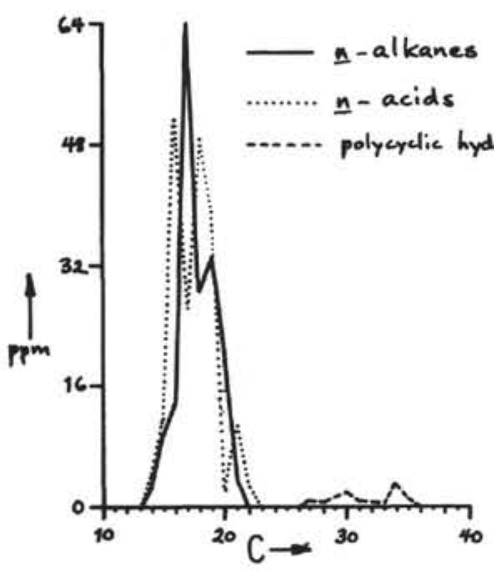

b

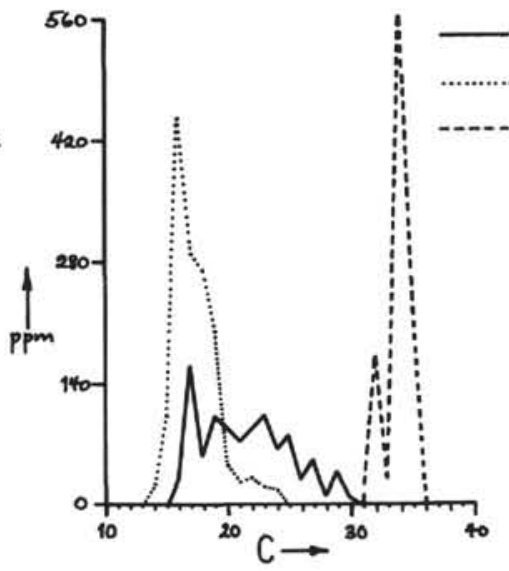

C

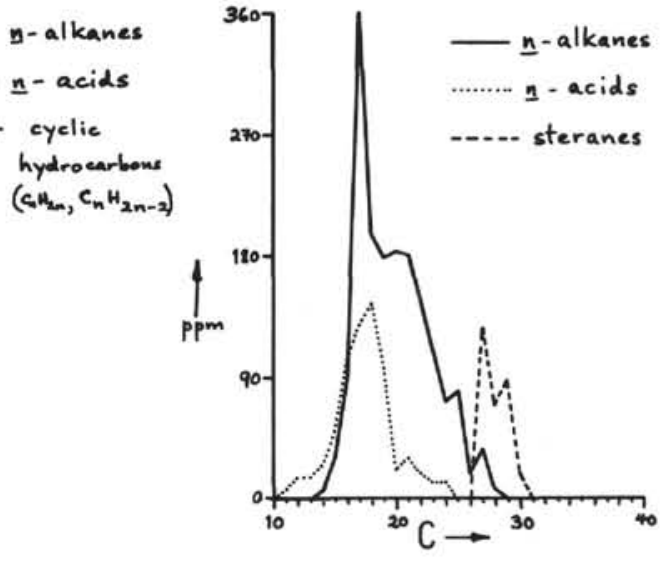

Figure 16. Homologous series distribution histograms for the Site 144 samples.

a) $14-144 A-5-1(114-116 \mathrm{~cm})$.

b) $14-144 A-6-1(100-101 \mathrm{~cm})$.

c) $14-144-4-3(14-15 \mathrm{~cm})$.

599 
Sample 14-144-4-3 (14-15 cm) contains mainly three homologous series: alkanes with no predominance and a maximum at $\mathrm{C}_{17}$; acids with no predominance and a maximum at $\mathrm{C}_{18}$; and steranes, consisting of cholestane ergostane, and sitostane (cf. Figure 16c). The narrow distribution envelope of the alkanes and acids and the sterane distribution indicate a marine source for the soluble organic matter.

The bulk of the organic matter in these Cretaceous samples consists of kerogen. The extractable petroliterous material appears to have derived from marine sources and has gone through diagenetic maturation.

\section{ACKNOWLEDGMENTS}

We thank Mr. Fred Walls for assistance with GC/MS and Miss Rosalynd Jackson and Dr. James Chang for assistance with high resolution mass spectrometry. The financial support from the Oceanography Section of the National Science Foundation (NSF Grant GA-24214) and from the National Aeronautics and Space Administration (NASA Grant NGL 05-003-003) is gratefully acknowledged.

\section{REFERENCES}

Arpino, P. and Ourisson, G. 1971. Interactions between rock and organic matter. Esterification and transesterification induced in sediments by methanol and ethanol. Anal. Cham. 43, 1656.

Budzikiewicz, H. and Djerassi, C., 1962. Mass spectrometry in structural and stereochemical problems. I. Steroid ketones. J. Am. Chem. Soc. 84, 1430.

Burlingame, A. L., 1968. Data acquisition, processing and interpretation via coupled high-speed real-time digital computer and high resolution mass spectrometer systems. In Advances in Mass Spectrometry, Vol. 4, E. Kendrick (Ed.). London (The Institute of Petroleum). 15 .

1970. Developments and applications of real-time high resolution mass spectrometry. In Recent Developments in Mass Spectroscopy, K. Ogata and T. Hayakawa (Eds.). Tokyo (University of Tokyo Press). 104.

Burlingame, A. L. and Smith, D. H., 1968. Automated heteroatomic plotting as an aid to the presentation and interpretation of high resolution mass spectral data. Tetrahedron. 24, 5749.

Burlingame, A. L., Smith, D. H., Merren, T. O. and Olsen, R. W., 1970. Real-time high resolution mass spectrometry. In Computers in Analytical Chemistry (Vol. 4, Progress in Analytical Chemistry Series), C. H. Orr and J. Norris (Eds). New York (Plenum Press). 17

Chang, J. J., Walls, F. C., Smith, D. H., Simoneit, B. R. and Burlingame, A. L., in preparation. The LOGOS compound classifier for background corrected low resolution mass spectral data. Anal. Chem.

Hayes, D. E., Pimm, A. C., Benson, W. E., Berger, W. H., von Rad, U., Supko P. R., Beckmann, J. P., Roth, P. H. and Musich, L. F., 1971. Deep Sea Drilling Project Leg 14. Geotimes. 16(2), 14.

Hayes, D. E., Pimm, A. C. et al., 1972. Initial Reports of the Deep Sea Drilling Project, Volume 14. Washington (U.S. Government Printing Office).
Maxwell, J. R., Douglas, A. G., Eglinton, G. and McCormick, A., 1968. The botryococcenes - hydrocarbons of novel structure from the alga Botryoccoccus braunii, Kützing. Phytochemistry. 7, 2157

Meyers, P. A. and Quinn, J. G., 1971. Fatty acid-clay mineral association in artificial and natural sea water solutions. Geochim. Cosmochim. Acta. 35, 628.

Simoneit, B. R., in press. Organic analyses of the Black Sea cores. In the Black Sea: Geology, Chemistry and Biology, E. T. Degens and D. A. Ross (Eds.). Am. Assoc. Petrol. Geologists Mem.

Simoneit, B. R. and Burlingame, A. L., 1971a. Some preliminary results on the higher weight hydrocarbons and fatty acids in the Deep Sea Drilling Project cores, Legs 5-7. In Winterer, E. L., Riedel, W. R. et al., 1971. Initial Reports of the Deep Sea Drilling Project, Volume 7. Washington (U.S. Government Printing Office). 889. , $1971 \mathrm{~b}$. Further preliminary results on the higher weight hydrocarbons and fatty acids in the Deep Sea Drilling Project cores, Legs 5-8. In Tracey, J. I., Jr., Sutton, G. H. et al., 1971. Initial Reports of the Deep Sea Drilling Project, Volume 8. Washington (U. S. Government Printing Office). 8973.

1972a. Further preliminary results on the higher weight hydrocarbons and fatty acids in the Deep Sea Drilling Project cores, Leg 9. In Hays, J. et al., 1972. Initial Reports of the Deep Sea Drilling Project, Volume 9. Washington (U.S. Government Printing Office). 859.

1972b. Preliminary organic analyses of the Deep Sea Drilling Project (JOIDES) cores, legs V-IX. In Advances in Organic Geochemistry 1971, H. R. von Gaertner and $\mathrm{H}$. Wehner (Eds.). Braunschwig (Pergamon-Vieweg). 189.

Simoneit, B. R., Scott, E. S., Howells, W. G. and Burlingame, A. L., 1972. Preliminary organic analyses of the Deep Sea Drilling Project cores from Leg 11. In Hollister, C. D., Ewing, J. I. et. al. 1972. Initial Reports of the Deep Sea Drilling Project, Volume 11. Washington (U.S. Government Printing Office). 1013.

Simoneit, B. R., Scott, E. S. and Burlingame, A. L., in press. Preliminary organic analyses of Deep Sea Drilling Project cores from Legs 12 and 13. In Ryan, W. B., Hsu, K. J. et al. Initial Reports of the Deep Sea Drilling Project, Volume 13. Washington (U.S. Government Printing Office).

in preparation. Preliminary organic analyses of the Deep Sea Drilling Project Cores, Leg 10. In Worzel, J. L., Bryant, W. et al. Initial Reports of the Deep Sea Drilling Project. Volume 10. Washington (U.S. Government Printing Office).

Simoneit, B. R., Howells, W. G. and Burlingame, A. L., in preparation. Preliminary organic geochemical analyses of the Cariaco Trench Site 147, Deep Sea Drilling Project, Leg 15. In Edgar, N. T., Saunders, J. B. et al. Initial Reports of the Deep Sea Drilling Project, Volume 15. Washington (U.S. Government Printing Office).

Smith, D. H., 1972. A compound classifier based on computer analysis of low resolution mass spectral data. Geochemical and environmental applications. Anal. Chem. 44, 536.

Smith, D. H., Olsen, R. W., Walls, F. C. and Burlingame, A. L., 1971. Real-time organic mass spectrometry: LOGOS - a generalized laboratory system for high and low resolution, GC/MS and closed-loop applications. Anal. Chem. 43, 1796. 